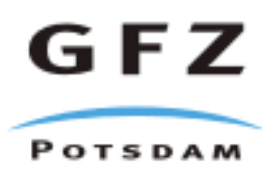

Originally published as:

Schnurr, W. B. W., Trumbull, R. B., Clavero, J., Hahne, K., Siebel, W., Gardeweg, M.

(2007): Twenty-five million years of felsic magmatism in the southern Central Volcanic Zone of the Andes: geochemistry and magma genesis of ignimbrites from $25-27^{\circ} \mathrm{S}, 67-72^{\circ} \mathrm{W}$. Journal of Volcanology and Geothermal Research, 166, 1, 17-46,

DOI: 10.1016/j.jvolgeores.2007.06.005. 


\title{
Twenty-five million years of silicic volcanism in the southern Central Volcanic Zone of the Andes: geochemistry and magma genesis of ignimbrites from $25-27^{\circ} \mathrm{S}, 67-72^{\circ} \mathrm{W}$
}

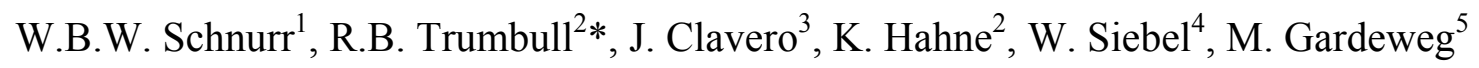 \\ 1 Freie Universität Berlin, Malteserstr. 74-100, 12249 Berlin, Germany \\ 2 GeoForschungsZentrum Potsdam, Telegrafenberg, 14473 Potsdam, Germany \\ 3 Servicio Nacional de Geología y Minería, Santiago, Chile \\ 4 Institut für Geowissenschaften, Universität Tübingen, 72074 Tübingen, Germany \\ 5 Aurum Consultores Servicios Geológicos y Mineros Ltda., Santiago, Chile
}

\begin{abstract}
Silicic volcanism in the Andean Central Volcanic Zone (CVZ) produced one of the world's largest Neogene ignimbrite provinces. The largest and best known CVZ ignimbrites are located on the Altiplano-Puna plateau north of $24^{\circ} \mathrm{S}$. Their compositions and huge erupted volumes suggest an origin by large-scale crustal melting, and present-day geophysical anomalies in this region suggest still active zones of partial melting in the middle crust. Farther south in the CVZ, the Cerro Galán complex erupted ignimbrites in the late Miocene and Pliocene that are quite similar in volume and composition to those from north of $24{ }^{\circ} \mathrm{S}$ and they have a similar origin. However, there are a great many other, smaller ignimbrites in the southern CVZ whose compositions and geodynamic significance are poorly known. These are the subject of this paper.
\end{abstract}

We present a geochemical study of 28 ignimbrite units from the southern $\mathrm{CVZ}$ at $25^{\circ} \mathrm{S}$ to $27^{\circ} \mathrm{S}$, whose ages cover the full span of arc activity in this area, from about $25 \mathrm{Ma}$ to 1 Ma. The small to medium volume igimbrites $\left(<10 \mathrm{~km}^{3}\right)$ form valley-fill or sheet-like deposits, many of which are chemically zoned. Notwithstanding individual differences, there are several common characteristic features within the group of southern CVZ ignimbrites. By far the dominant composition is metaluminous, crystal-poor rhyolite (mean values from 236 samples: $\mathrm{SiO}_{2}=73.5$ wt. $\%, \mathrm{~A} / \mathrm{CNK}=1.02, \mathrm{~K}_{2} \mathrm{O} / \mathrm{Na}_{2} \mathrm{O}=1.4$ ). Regular major and trace element differentiation trends suggest fractionation from intermediate arc magmas and this is supported by radiogenic isotopic ratios of $\mathrm{Sr}, \mathrm{Nd}$ and $\mathrm{Pb}$, which show complete overlap between the silicic ignimbrites and andesite-dacites from contemporary stratovolcanoes. There are no major changes in composition of the silicic ignimbrites over the $25 \mathrm{Ma}$ span of 
activity. We attribute minor but significant differences in isotopic composition and $\mathrm{Nb}-\mathrm{Ta}$ concentration according to location in the West Cordillera (Chile) or the southern Puna plateau (Argentina) to variations in local basement compositions.

The major conclusion of this study is that silicic magmas of crustal origin are rare in the CVZ south of $24^{\circ} \mathrm{S}$, and the only known example, Cerro Galán, is considerably younger than the ignimbrite "flare-up" in the Altiplano-Puna plateau region. The thermal conditions for widespread crustal melting in the Altiplano-Puna north of $24^{\circ} \mathrm{S}$ are related to increased mantle heat flux caused by slab steepening and/or delamination at the base of overthickened lithosphere. These conditions have not (yet) been achieved in the southern CVZ because of the southward shallowing of slab dip and younging of compressive deformation and plateau growth.

Keywords: Central Andes, Puna, ignimbrites, Galán, geochemistry, Sr, Nd, Pb isotopes

*Corresponding author:

GeoForschungsZentrum Potsdam, Telegrafenberg B125, 14473 Potsdam, Germany email: bobby@gfz-potsdam.de

Tel: +49-331-2881495, Fax: +49-331-2881474 


\section{Introduction}

The abundance of silicic magmas is one of the most prominent characteristics of the Neogene magmatic arc in the Central Andes (Central Volcanic Zone, CVZ). The large silicic eruptions in the CVZ were not distributed evenly in time and space but concentrated in certain ages and locations as ignimbrite "flare-ups" (de Silva, 2004, de Silva et al., 2006). By far the largest of these, and one of the great Neogene ignimbrite provinces world-wide, is the concentration of Miocene to Pliocene resurgent caldera complexes in the Altiplano-Puna Volcanic Complex, or APVC (de Silva, 1989) near the Chile-Argentina-Bolivia common border (Fig. 1). Well-studied calderas within the APVC include La Pacana (Gardeweg and Ramirez, 1987; Lindsay et al., 2001 a,b; Schmitt et al., 2001, 2002), Panizos (Ort, 1993; Ort et al., 1996), Vilama-Coruto complex (Coira et al., 1996) and Coranzuli in NW Argentina (Seggiaro, 1994). The large ignimbrites of the APVC comprise erupted volumes on the order of several thousands of cubic kilometers and they show geochemical evidence of having a dominantly crustal source. There is also compelling evidence from seismic velocity and electrical conductivity anomalies that a broad zone of high temperatures and partial melt persists in the mid-crust under the plateau region today (Brasse et al., 2002; Zandt et al., 2003; Schilling et al., 2006). These ignimbrites are geologic expressions of enormous thermal anomalies in the crust, and their space-time distribution is of obvious importance for tectonic and geodynamic interpretations.

All the examples mentioned above are located in the APVC region from about $21^{\circ} \mathrm{S}$ to $24{ }^{\circ} \mathrm{S}$ (Fig. 1) but silicic ignimbrites are also widespread in the CVZ south of the APVC. The latter have been comparatively poorly studied as a group. Most of the ignimbrite units have been described and dated in conjunction with geologic mapping, but few of them were subjects of a geochemical and petrologic study. Some units have been described in geochemical studies of volcanism in specific regions (e.g., Kay et al., 1994b; Kraemer et al., 1999; Richards and Villeneuve, 2002; Richards et al., 2006). The only example that was the subject of a detailed study is Cerro Galán, which was active from about $6 \mathrm{Ma}$ to $2 \mathrm{Ma}$ (Sparks et al., 1985; Francis et al., 1989). The ignimbrites from Cerro Galán are similar to those from the APVC in that they have extremely large eruptive volumes, rhyodacite bulk composition and crustal isotopic signatures. However, other ignimbrites in the southern CVZ appear to differ from the "Galán type" in a number of important ways. They are smaller in volume, tend to be more highly silicic and less homogeneous in composition, and their age distribution is spread more or less evenly through the history of the arc, compared to the episodic occurrence 
of ignimbrites in the north (Coira et al., 1993). Finally, the available isotopic data (Thorpe et al., 1979; Kay et al., 1994b; Siebel et al., 2001) suggest that the southern CVZ ignimbrites lack the strong crustal signatures that are distinctive of the Gálan and APVC ignimbrites.

The motivation of the present study was to achieve a representative and comprehensive geochemical overview of silicic volcanism in the southern $\mathrm{CVZ}$ and to consider them in the context of the tectono-magmatic evolution of this segment of the arc. Emphasis is placed on the following aspects: (i) The origin of silicic magmas and their pre-eruptive evolution, in particular the role of crustal melting vs. differentiation of intermediate magmas, (ii) The variations or uniformity of ignimbrite compositions as a function of age and location in the Western Cordillera (Chile) vs. the Puna plateau (Argentina), and (iii) The relationships between the silicic magmas represented by ignimbrites and the mafic to intermediate rocks from contemporary arc volcanic centers. The basis for the study is a geochemical and radiogenic isotope dataset representing a total of 28 units apart from the Galán ignimbrites, which were sampled between $25^{\circ} \mathrm{S}$ and $27^{\circ} \mathrm{S}$ and whose ages range from early Miocene to Pleistocene. Our sampling was limited to radiometrically dated units whose geologicstratigraphic positions were established by regional geologic maps in Chile (Naranjo and Cornejo, 1992; Clavero et al., 2006a, b) and Argentina (Seggiaro and Hongn, 2003; Seggiaro et al., 2006).

\section{Geologic background}

\subsection{The geodynamic setting: Altiplano-Puna plateau and subduction geometry}

Since this paper is concerned with the nature of ignimbrites in the southern part of the Central Volcanic Zone in relation to those erupted farther north, it is worth reviewing evidence for major differences from north to south in the Central Andes in terms of the geologic history, lithospheric structure and subduction geometry (present and past). Details of these differences were reviewed by Allmendinger et al. (1997 and references therein), and here we briefly list some of the most relevant points. Relative to the Altiplano plateau (north of $22^{\circ} \mathrm{S}$ ), the Puna has a higher average elevation and more rugged topography, the Puna crust is thinner (42-66 km vs. $62-80 \mathrm{~km}$ for the Altiplano: Yuan et al., 2002) and the extent of horizontal shortening across the Puna plateau is also less. This suggests that the high elevation of the Puna has a dynamic support from a more buoyant, hotter mantle, which is consistent with differences in seismic wave attenuations (Whitmann et al., 1992) and forms 
one of the key arguments in favor of late Cenozoic delamination of the lithosphere under the southern Puna plateau (Kay and Kay, 1993; Kay et al., 1994a). Another difference is that the Altiplano plateau is bordered to the east by the broad, thin-skinned Subandean fold and thrust belt, whereas the foreland east of the Puna plateau is formed by the thick-skinned Santa Barbara System and the Sierras Pampeanas. Seggiaro and Hongn (1999) and Kley et al. (1999) emphasized this contrast in ridigity of the Altiplano and Puna forelands and its influence on the style of deformation as well as on the distribution of late Cenozoic volcanism.

The timing of plateau formation differs from north to south. Horizontal compression and crustal shortening across the Altiplano plateau began in the late Eocene/early Oligocene (40-35 Ma), then intensified greatly from about 29-20 Ma and continued until about 10-6 Ma (Allmendinger et al., 1997; Gregory-Wodzicki, 2000; Oncken et al., 2006). In the southern Puna plateau, the onset of shortening deformation was later, about $20 \mathrm{Ma}$, and it continued until about 1-2 Ma (Allmendinger et al., 1997; Marrett et al., 1994). Riller and Oncken (2003) also inferred a progressive north-to-south younging of plateau development from $18{ }^{\circ} \mathrm{S}$ to 29 ${ }^{\circ} \mathrm{S}$ based on sedimentation ages marking the establishment of closed basins.

Finally, there are differences in the dip angle of the subducting Nazca plate beneath the northern and southern plateau regions, which are well constrained by seismicity. North of about $24{ }^{\circ} \mathrm{S}$ the Nazca plate subducts at an angle of 25 to 30 degrees beneath the Andean margin (Cahill and Isacks, 1992; Graeber and Asch, 1999; Gutscher et al., 2000) and the dip angle diminishes southward until the "flat-slab" region of $28-33{ }^{\circ} \mathrm{S}$ is reached. Information on the subduction dip angle in the geologic past is given by the position and width of the volcanic arc. These parameters have changed with time and more importantly, in different ways north to south (e.g. Coira et al., 1993, Kay et al., 1999; Trumbull et al., 2006). Whereas arc magmatism from about $28^{\circ} \mathrm{S}$ to $33^{\circ} \mathrm{S}$ is absent due to flat subduction, there was vigorous activity in this region prior to about $6 \mathrm{Ma}$, suggesting a steeper subduction angle at that time (Kay and Abruzzi, 1996). And conversely, in the region of moderate slab dip today (north of $24^{\circ} \mathrm{S}$ ), broadly dispersed arc volcanism in the late Oligocene and early Miocene suggest a much shallower dip at that time (Kay et al., 1999). In terms of these inferred changes in subduction angle with time and place along the arc, the southern CVZ occupies a kind of hinge zone, where the present slab dip is intermediate relative to the segments north and south, and where changes in dip angle have been less pronounced. This relatively constant subduction geometry in the Cenozoic is apparently one reason why arc volcanism in this 
region has been more or less continuous for 20-25 million years, and the longevity of magma production in turn may help explain the relatively high abundance of strongly evolved silicic magmas in the arc compared with regions to the north, as discussed in section 5.2.

\subsection{Basement compositions}

In the area of this study, pre-Mesozoic basement rocks are largely buried under Cenozoic terrestrial sedimentary rocks and volcanic cover, but existing exposures show a predominance of silicic rock types, comprising crustal derived granitoids with Ordovician ages, mica schists, orthogneisses and migmatites (Sparks et al., 1985; Becchio et al., 1999; Kraemer et al., 1999; Coira et al., 1999; Kasemann et al., 2000; Lucassen et al., 2001; 2005; Richards et al., 2006). Two main episodes of regional metamorphism and magmatism are recognized, one at about $500 \mathrm{Ma}$ attributed to the Pampean Cycle and a younger, Ordovician to Devonian episode related to the Famatinian Cycle (see reviews by Pankhurst et al., 1998, Rapela et al., 1998, and Franz et al., 2006). Based on the rather patchy exposures, there appear to be significant compositional differences within the pre-Mesozoic basement from east to west in the study area. The basement gneisses east of the Chile-Argentina border tend to have more radiogenic $\mathrm{Pb}$ and $\mathrm{Sr}$, and less radiogenic $\mathrm{Nd}$ isotopic composition than those farther west in Chile (Lucassen et al., 2001). Coira et al. (1993) and Coira and Kay (2004) also pointed out west-to-east differences in the isotopic ratios of large-volume Neogene ignimbrites from the APVC region, and attributed them to changes in basement composition and/or to the effects of long-term additions of arc magmas into the crust. Evidence for basement influence in the southern CVZ magma compositions is discussed in section 5.1 below.

\subsection{Time-space patterns of volcanism}

Cenozoic volcanism in the CVZ comprises three volcanic associations (Coira et al., 1982; 1993), all of which are represented in the study area: (i) Early Miocene to Pleistocene andesite-dacite stratovolcanoes of the main arc (ii) Early Miocene to Pliocene silicic ignimbrite deposits and lava domes that occur in the main arc and back-arc regions, and (iii) small, Pliocene to Pleistocene basaltic centers in the back arc. In the area of interest, between about $25^{\circ} \mathrm{S}$ and $27^{\circ} \mathrm{S}$, arc magmatism has been ongoing from the early Miocene to the present day. The oldest arc volcanoes recognized in the region are the andesitic and basaltic andesitic centers León Muerto (20 Ma) and Cerro Colorado (19.5 Ma), both located in the 
Chilean Western Cordillera (Fig. 1). The oldest prominent stratovolcanoes in the southern Puna of Argentina formed at about $14 \mathrm{Ma}$ (Cerro Beltrán and Cerro Tebenquicho) but there are signs of earlier activity as well. Coira and Kay (1999) dated deeply eroded andesite-dacite centers from the Salar de Aguas Calientes area at 23-20 Ma, and Kraemer et al. (1999) reported ages of $18 \mathrm{Ma}$ for andesitic boulders in the Potrero Grande Formation and $22 \mathrm{Ma}$ for an andesitic lava NE of Cerro Peinado, both in the Salar de Antofalla area. Stratovolcanoes remained active in the Western Cordillera of Chile through the Pleistocene and up to today (e.g. Lastarría, Bayo, Falso Azufre, Condor, Sierra Nevada, Llullaillaco) but in Argentina, this type of volcanism became rare after the late Miocene. Instead, Pliocene to Pleistocene volcanism involved small, monogenetic centers that erupted basaltic andesite and andesite lavas with more back-arc chemical affinities. A few post-Miocene stratovolcanoes do occur well to the east of the arc front in Argentina, a prominent example being Cerro Tuzgle (Coira and Kay, 1993). However, their location appears to be controlled by major cross-arc lineament zones such as the Calama- Olacapato-El Toro zone at ca. $24{ }^{\circ} \mathrm{S}$ and the Archibarca lineament. The latter intersects our study area (see inset to Fig. 1). The volcanic centers along these zones have been described by Richards and Villeneuve (2002), Matteini et al. (2002) and Arnosio (2002).

\section{Silicic ignimbrites in the Southern CVZ}

The ignimbrite units described in this paper are pyroclastic flow deposits of sheet-like or valley-fill aspect. Many of them contain multiple flow units and there are commonly associated ground surge and airfall deposits at the basement contacts or between flow units. As described in the following section, most of the sampled units have rhyolitic bulk compositions. Table 1 lists the names and ages of the main ignimbrite units covered in this study, based on published geologic maps in Chile and Argentina (see Table for age sources). The units for which compositional data are presented here are outlined in bold type. The approximate locations of the units are shown on Figure 2 and sample coordinates are given in the tables and supplementary electronic data. The ignimbrite ages document an overall $25 \mathrm{Ma}$ time span of silicic volcanism in the southern CVZ, and they also show apparent differences in the onset of silicic magmatism across the region. In the Chilean West Cordillera, the oldest ignimbrites are late Oligocene in age (Rio Frio, 25-18 Ma) and several units have midMiocene ages. In Argentina, only a single mid-Miocene ignimbrite is known (Quebrada 
Honda, 17-18 Ma) and no older ones have been recognized. Ignimbrite activity was widespread all across the region in the late Miocene and Pliocene, and Pleistocene units are also present in both Chile and Argentina.

Many of the ignimbrite units in the southern CVZ occur as areally extensive deposits that are prominent on satellite images (Fig. 2). Some of these units have been related to source calderas (e.g., Wheelwright caldera and the Wheelwright ignimbrite, Laguna Amarga caldera and the Laguna Amarga and Laguna Verde ignimbrites; Cerro Blanco caldera and the Rosada and Cerro Blanco ignimbrites). Other units occur as valley-fill deposits and several of these are radially dispersed around a stratovolcano and clearly erupted from it. Examples of the latter are the Cerro Escorial volcano and the Escorial ignimbrite (Richards and Villeneuve, 2002), Archibarca volcano and the Caballo Muerto and Archibarca ignimbrites (Schnurr, 2002), Cerro Tridente volcano and the Vallecito ignimbrite (Seggiaro and Hongn, 2003); or Cerro Bayo and the Quebrada de las Cuevas ignimbrite (Richards et al., 2006). However, the eruptive source for many of the ignimbrite units listed in Table 1 is not yet known, which hampers making correlations of units across the Chile-Argentina border and assessing total erupted volumes of the units. First-order estimates of eruptive volumes are $<10$ $\mathrm{km}^{3}$ for most units based on the areal extent measured from maps and satellite images combined with typical stratigraphic thicknesses (Kraemer et al., 1999; Schnurr, 2002). An exceptionally large example is the Rio Frio ignimbrite, which is on the order of $100 \mathrm{~km}^{3}$ in volume (Naranjo and Cornejo, 1992); its eruptive source is not known. The Late Pliocene eruption of $>1000 \mathrm{~km}^{3}$ of dacitic ignimbrites from Cerro Galán (2.2 Ma) in Argentina appears to have been a singular event in the region, with no equivalents in either volume or composition.

With few exceptions, the ignimbrites studied here are pumice-bearing, and pumice fragments are crystal-poor ( $<1-5$ vol.-\%), with fine-grained quartz, plagioclase, biotite, magnetite and ilmenite as the main phenocryst phases. Hornblende, orthopyroxene and sanidine phenocrysts are prominent in only a few units. The degree of welding varies according to thickness and proximity to source. More comprehensive descriptions of individual units in Argentina are given in Schnurr (2002), Siebel et al. (2001), Richards et al. (2006) and Seggiaro et al. (2003; 2006). Ignimbrite units in Chile are described in Naranjo and Cornejo (1992), Siebel et al. (2001) and Clavero et al. (2006a, b). 


\section{Geochemistry}

\subsection{Sampling and analytical methods}

This study comprises about 280 samples representing 28 ignimbrite units from the southern CVZ excluding those from Cerro Galán. The scope of sampling was intended to provide reasonably complete coverage of the units, enabling a description of their group characteristics, an assessment of regional variations in composition according to age and location, and a comparison with the large-volume ignimbrites from Galán and the APVC. Care was taken to sample any internal units and other apparent variations in the various sections, but we cannot address the details of composition or petrogenesis of individual ignimbrites here.

The ignimbrite analyses represent single or composite pumice samples except for a very few units where pumice was lacking. For the latter, matrix tuff was cleaned of any lithic fragments by hand-picking prior to analysis and these samples are designated as "matrix" in the data tables. The geochemical database includes X-ray fluorescence analyses of all samples for the major elements, $\mathrm{Cr}, \mathrm{V}, \mathrm{Ni}, \mathrm{Rb}, \mathrm{Sr}, \mathrm{Ba}, \mathrm{Zn}, \mathrm{Zr}, \mathrm{Nb}$ and $\mathrm{Y}$; and analyses of a subset of these by ICP-AES for the REE and by ICP-MS for U, Th, Pb, Ta, Ga, Sc, Li, Cs, Cu, Mo and Sn. All sample preparation and chemical analyses were performed at the GeoForschungsZentrum Potsdam using methods described in Lindsay et al. (2001b). Isotope ratios of $\mathrm{Sr}, \mathrm{Nd}$ and $\mathrm{Pb}$ were determined on whole-rock samples at the University of Tübingen, using the chemical separation and measurement techniques described by Siebel et al. (2001). Petrographic study of thin sections showed that alteration is generally weak but several samples show signs of vapor-phase alteration, with fine-grained mineralization of sericite and local carbonate in the groundmass. Many of these samples stand out geochemically by having high $\mathrm{H}_{2} \mathrm{O}$ and $\mathrm{CO}_{2}$ concentrations (up to $7.7 \mathrm{wt} . \%$ and $6 \mathrm{wt} . \%$, respectively) and by showing deviations from normal differentiation trends of the more fluidmobile major elements (e.g., $\mathrm{Ca}, \mathrm{Na}, \mathrm{K}$ ). To minimize this problem we do not plot samples with more than 4 wt. $\% \mathrm{H}_{2} \mathrm{O}$ and 0.5 wt. $\% \mathrm{CO}_{2}$ (or 4 wt. $\%$ loss on ignition), which excludes 33 of 277 samples.

Most of the compositional data presented for the andesite-dacite centers in the study area were taken from the studies by Trumbull et al. (1999) for the Salar de la Isla region in Chile, and from Kraemer et al. (1999) for the Salar de Antofalla area in Argentina (Fig. 1). In addition, we carried out 14 new whole-rock analyses of andesite-dacite samples (Table 3) and 
10 analyses of $\mathrm{Sr}, \mathrm{Nd}$, and $\mathrm{Pb}$ isotope composition (Table 4) to achieve a comparable coverage of this volcanic association and ignimbrites. Selections of representative analyses for the ignimbrite units are given in Table 2, and the complete data set is provided as supplementary material to this paper. For all of the geochemical diagrams presented in this section, major element concentrations were recalculated before plotting to sum to $100 \mathrm{wt}$. \% on a water and $\mathrm{CO}_{2}$-free basis.

\subsection{Major and trace element compositions}

The large number of ignimbrite units covered in this study makes it impractical to describe their compositions individually. Instead, we identify the general geochemical characteristics of the ignimbrite units from the southern CVZ, show their overall compositional ranges, focus on aspects most relevant to magma genesis, and assess possible changes in time and space within the region. To avoid clutter in the diagrams the ignimbrites are plotted according to age groupings and not individually, which also allows direct comparisons of age vs. composition. All of the geochemical diagrams and text descriptions are based on the filtered data set $\left(<4\right.$ wt. $\% \mathrm{H}_{2} \mathrm{O},<0.5$ wt. $\left.\% \mathrm{CO}_{2}\right)$, whereas the tables and supplementary material present original data.

Overall, the southern CVZ ignimbrites included in this study have compositions extending from silica-rich andesite to rhyolite (Fig. 3a). However, andesitic compositions are limited to the mid-Miocene La Ola ignimbrite (ave. $\mathrm{SiO}_{2}=60$ wt.\%, $\mathrm{n}=13$ ). Rhyolitic compositions dominate, and the average $\mathrm{SiO}_{2}$ concentration of the data set is $73.5 \mathrm{wt} \%$ (Fig. 3b). Excepting the La Ola unit, the ignimbrites are potassic, with the $\mathrm{K}_{2} \mathrm{O} / \mathrm{Na}_{2} \mathrm{O}$ weight ratios greater than unity (Fig. 3a). Few of the samples are strongly peraluminous, and the average $\mathrm{A} / \mathrm{CNK}$ ratio (molar $\mathrm{Al}_{2} \mathrm{O}_{3} / \mathrm{CaO}+\mathrm{Na}_{2} \mathrm{O}+\mathrm{K}_{2} \mathrm{O}$ ) is 1.02 (Fig. 3c). One of the main results of this study is that as a group, the southern CVZ ignimbrites are much more silicic than the large-volume ignimbrites erupted from Cerro Galán (stars on a shaded field in Fig. 3a), and also more variable in composition. The Galán ignimbrites and the large-volume ignimbrites of the APVC, have restricted silica ranges of 65-70 wt.\% $\mathrm{SiO}_{2}$ (de Silva, 1991; Francis et al., 1989; Ort et al., 1996). Rhyolitic ignimbrites ( $\left.>70 \mathrm{wt} . \% \mathrm{SiO}_{2}\right)$ are not unknown in the APVC (e.g., Carcote ignimbrite, Baker, 1977; Caspana and Chaxas ignimbrites: de Silva, 1991; Toconao ignimbrite: Lindsay et al., 2001b), but they are far fewer in number and much smaller in volume than the dacitic ignimbrites. 
Many of the southern CVZ ignimbrites are compositionally variable, with typical $\mathrm{SiO}_{2}$ ranges of 4-6 wt.\% (Fig. 4). Where vertical profiles were sampled (e.g., Archibarca lower and upper units), the lower samples are generally more silica-rich, which is consistent with a model of roof-downward tapping of magma chambers with more differentiated tops. The different slopes and lengths of trend lines for $\mathrm{K}_{2} \mathrm{O}$ vs. $\mathrm{SiO}_{2}$ on Figure 4 indicate differences in the degree and manner of internal differentiation for individual units but there is also a considerable similarity within the group of units. Also shown for comparison is the regression line for $\mathrm{K}_{2} \mathrm{O}-\mathrm{SiO}_{2}$ variations in data from contemporary arc andesite-dacites. Many of the ignimbrite units appear to be essentially homogeneous in composition (but some are undersampled, see legend on Fig. 4). An interpretation of internal variations, or lack thereof, in the ignimbrite units is beyond the scope of this study, but it is interesting to note that nearly all of the homogeneous units plot at the silica-rich end of the total compositional range on Figure 4. A possible explanation for this observation is that the homogeneous ignimbrites represent eruptions that tapped only the differentiated top of zoned magma chambers.

Notwithstanding their individual differences, the ignimbrites as a group define regular trend lines on many major and trace-element variation diagrams when plotted against a differentiation index (Fig. 5). The variation trends suggest that fractional crystallization was important in evolution of the silicic magmas. Furthermore, the ignimbrite data plot close to or in extension of, trend lines defined by data from contemporary andesite-dacite volcanoes (dashed lines on Fig. 5). This supports the suggestion that many of the ignimbrites from the southern CVZ formed by differentiation of intermediate magmas (Siebel et al., 2001; Richardson et al., 2006) as discussed in more detail in section 5.2. Note in comparison the very narrow compositional range of the dacitic ignimbrites from Cerro Galán (stars on shaded field). There are of course individual complexities of ignimbrite compositions (compare Fig. 4) and a good illustration of this is the Ba plot (Fig. 5e). Most of the ignimbrite data plot on this diagram near the andesite-dacite trend line, with rising $\mathrm{Ba}$ at falling $\mathrm{Fe}$, until about 2 wt. $\% \mathrm{Fe}_{2} \mathrm{O}_{3}$ after which $\mathrm{Ba}$ concentrations decrease with further differentiation, probably due to a change in the phenocryst assemblage. Other units, the Tal and Archibarca ignimbrites particularly, do not follow this pattern and have exceptionally high Ba contents (>1000 ppm) at low iron concentration. The plot of $\mathrm{Zr}$ concentrations also shows a kinked differentiation trend (Fig. 5f), with the inflection point at about the same place as on the Ba plot $\left(\mathrm{Fe}_{2} \mathrm{O}_{3}=2\right.$ wt.\%). This supports the interpretation of a late-stage change in the fractionating assemblage (for $\mathrm{Zr}$, zircon and for $\mathrm{Ba}$, biotite and/or sanidine). A further example of trace element 
variations suggesting fractional crystallization is the relationship between Sr concentrations and the $\mathrm{Eu} / \mathrm{Eu} *$ ratio (Fig. 6a). Samples with greater than about $100 \mathrm{ppm}$ Sr follow the trend line defined by the andesite-dacite data, whereas the more evolved ignimbrites define a more shallow differentiation trend. The inflection point corresponds to an $\mathrm{Fe}_{2} \mathrm{O}_{3}$ value of about 1.5 wt.\%, similar to the $\mathrm{Ba}$ and $\mathrm{Zr}$ trends. An explanation for the kinked trend in $\mathrm{Sr} v \mathrm{vs}$. $\mathrm{Eu} / \mathrm{Eu}^{*}$ is the late entry of sanidine into the fractionating assemblage, since Eu partitions subequally in both feldspars relative to melt, whereas $\mathrm{Sr}$ is less compatible in sanidine than in sodic plagioclase (Blundy and Wood, 1991). Note also that the increasingly negative Eu anomaly in the more evolved silicic ignimbrites is accompanied by falling concentrations of the LREE, producing lower La/Sm ratios (Fig. 6b).

The wide range in $\mathrm{La} / \mathrm{Sm}$ ratios correlate well with $\mathrm{Sm} / \mathrm{Yb}$ (Fig. 6b), consistent with expected differentiation trends for magmas crystallizing amphibole, which depletes the melt in the middle REE particularly, and accessory phases like monazite or allanite which selectively remove La and Ce. In support of this inference, the samples with the lowest La concentrations $(<10 \mathrm{ppm})$ and $\mathrm{La} / \mathrm{Sm}$ ratios, have high $\mathrm{Rb} / \mathrm{Sr}$ and low values of $\mathrm{Eu} / \mathrm{Eu}$ *. The southern CVZ ignimbrites in our data set have only moderate $\mathrm{Sm} / \mathrm{Yb}$ ratios and typical concave-upward REE patterns (Fig. 7) which are consistent with amphibole fractionation (Richardson et al., 2006). In contrast, the dacitic ignimbrites from Cerro Galán and Panizos (in the APVC), as well as some of the andesite-dacite centers (Fig. 6b) reach high $\mathrm{Sm} / \mathrm{Yb}$ values at moderate $\mathrm{La} / \mathrm{Sm}$, which is best explained by HREE removal or retention in residual garnet during magma evolution in a lower crustal MASH zone (Hildreth and Moorbath, 1988; Kay et al., 1999; Haschke et al. 2002).

\subsection{Radiogenic isotopes}

The isotope data reported in Siebel et al. (2001) for the southern CVZ ignimbrite units, and data for the contemporary andesite-dacite volcanics from Trumbull et al. (1999) and Kraemer et al. (1999) are combined in this section with new results from an additional 10 analyses (3 ignimbrite units, 7 andesite-dacites). The new isotopic data are presented in Table 4 and the combined dataset is used in the subsequent diagrams, with ignimbrite samples grouped according to age and data for the andesite-dacite centers plotted as black dots.

The initial ${ }^{87} \mathrm{Sr} /{ }^{86} \mathrm{Sr}$ ratios of the southern $\mathrm{CVZ}$ ignimbrites vary between 0.7066 and 0.7090 and corresponding values of $\varepsilon \mathrm{Nd}(\mathrm{t})$ are between -2.4 and -5.0 (Fig. 8a). The key point to note here is that the $\mathrm{Sr}$ and $\mathrm{Nd}$ isotope ratios of silicic $\mathrm{CVZ}$ ignimbrites overlap completely 
with isotope compositions of associated arc volcanics and are distinctly different from those from the nearby Cerro Galán complex and from the APVC region north of $24{ }^{\circ} \mathrm{S}$ (Siebel et al., 2001). We emphasize that the distinct $\mathrm{Sr}$ and $\mathrm{Nd}$ isotopic compositions of ignimbrites from Cerro Galán holds not only for the 2 Ma Cerro Galán ignimbrite (black stars) but also for the older Merihuaca (5.4 Ma) and Real Grande (4.2 Ma) ignimbrites shown in open stars (data and ages from Francis et al., 1989). Therefore, it seems that throughout an eruptive history of over $3 \mathrm{Ma}$, silicic magmas from the Galán center had a distinctly greater crustal input than the other regional ignimbrites in the southern CVZ. The same is true for the high $\mathrm{Sm} / \mathrm{Yb}$ ratios of Galán ignimbrites (Fig. 6b) and the implications for melting and assimilation processes involving garnet-bearing assemblages in the lower crust.

The silicic ignimbrites and andesite-dacites also overlap in their $\mathrm{Pb}$ isotope compositions (Fig. 8b). Only ${ }^{206} \mathrm{~Pb} /{ }^{204} \mathrm{~Pb}$ ratios are plotted to save space; the ${ }^{207} \mathrm{~Pb} /{ }^{204} \mathrm{~Pb}$ and ${ }^{208} \mathrm{~Pb} /{ }^{204} \mathrm{~Pb}$ ratios show essentially identical features. In contrast to the $\mathrm{Sr}$ and $\mathrm{Nd}$ isotope data, the $\mathrm{Pb}$ isotopes show no gap in composition between the small-volume silicic ignimbrites and andesite-dacites on the one hand, and the large-volume dacitic Cerro Galán and APVC ignimbrites on the other. This makes sense because $\mathrm{Pb}$ isotope compositions are more sensitive to crustal influence than $\mathrm{Sr}$ or $\mathrm{Nd}$ since the continental crust is rich in $\mathrm{Pb}$ compared with parental arc magmas. Therefore, the $\mathrm{Pb}$ in even moderately-contaminated andesitedacites and silicic ignimbrites is already dominated by the crustal component. The $\mathrm{Pb}$ isotope data reveal that two ignimbrite units, Vallecito and Parinas (labeled on Fig. 8b), have particularly high ${ }^{206} \mathrm{~Pb} /{ }^{204} \mathrm{~Pb}$ ratios (confirmed by repeat analysis). These samples also have high ${ }^{207} \mathrm{~Pb} /{ }^{204} \mathrm{~Pb}$ and ${ }^{208} \mathrm{~Pb} /{ }^{204} \mathrm{~Pb}$, but they do not stand out in terms of their Sr and Nd isotope ratios so the unusual $\mathrm{Pb}$ isotopic composition is probably a reflection of local basement heterogeneity in $\mathrm{Pb}$ (Wörner et al., 1992; Aitcheson et al., 1995; Lucassen et al., 2001). 


\section{Discussion}

\subsection{Compositional variations with time and space}

The 25 million-year age range of silicic ignimbrites in the southern CVZ spans a time of significant change in the subduction rate and steepness, and particularly in the thickness and deformation regime of the crust. It is well established that the compositions of mafic to intermediate arc magmas show signs of these changes, as shown by studies of Walker et al. (1991), Kay et al. (1994b), Trumbull et al. (1999) and Kay and Mpodozis (2002). In this section we examine the time-space relationships of magma compositions using the combined information on andesite-dacites and the silicic ignimbrites from the southern CVZ. The focus is on isotopic ratios because they relate most directly to magma source variations and also because they are insensitive to variations in differentiation.

The $\mathrm{Sr}, \mathrm{Nd}$ and $\mathrm{Pb}$ isotope ratios of southern $\mathrm{CVZ}$ andesites and ignimbrites are plotted against age on Figure 9, with separate diagrams for locations in the Western Cordillera (Chile) and the Puna (Argentina). The andesite-dacite data from Chile (filled circles) show systematic age variations in isotopic composition, such that the younger magmas have stronger crustal input. Parallel changes in the $\mathrm{Rb}, \mathrm{Cs}$ and Th concentrations in these samples, not shown here (see Trumbull et al. 1999), are consistent with the isotope data and suggest an acceleration of crustal assimilation in the arc magmas in the late Miocene. The study by Trumbull et al. (1999) did not include data from Argentina, and the plots on Figure 9 show that the andesite-dacite samples from Argentina (open circles) lack systematic variations with age, although one should note that the data coverage is relatively poor. Turning to the ignimbrites, the main point to make is that their isotopic compositions vary much less with age than the andesite-dacites, and have no systematic differences according to E-W location. $\mathrm{The} \mathrm{Sr}, \mathrm{Nd}$ and $\mathrm{Pb}$ isotope ratios of ignimbrites of all ages from Chilean localities are similar to those of the young andesite-dacites, i.e. those with the strongest crustal influence. The compositions of ignimbrites and andesite-dacites from Argentina show considerable scatter, but the ignimbrites in this region tend to have lower initial ${ }^{87} \mathrm{Sr} /{ }^{86} \mathrm{Sr}$ ratios and higher values of ${ }^{143} \mathrm{Nd} /{ }^{144} \mathrm{Nd}$ than the associated intermediate magmas, i.e. they show less crustal assimilation. The ${ }^{206} \mathrm{~Pb} /{ }^{204} \mathrm{~Pb}$ ratios of both associations are the same and are very uniform, which underscores the point made in Figure $8 \mathrm{~b}$ that $\mathrm{Pb}$ compositions in the intermediate and silicic arc magmas are dominated by the crust. 
The trace element compositions of silicic ignimbrites in our data set show very little correlation with age of the units or with their $\mathrm{E}-\mathrm{W}$ location. Even the $\mathrm{Ba} / \mathrm{La}$ and $\mathrm{Ba} / \mathrm{Ta}$ ratios or other LIL/HFS element ratios, which commonly vary across-arc and are used to distinguish frontal vs. back-arc settings, show no consistent E-W differences (Fig. 10a). The only exception to a complete lack of systematic across-arc chemical variations are differences in the $\mathrm{Nb}$ and Ta concentrations, which are higher in samples from Argentina relative to those from Chile in both the andesite-dacite and ignimbrite associations (Fig. 10b).

It is difficult to determine the reason for these rather subtle across-arc differences in magma compositions: whether they existed in the parental magmas or were introduced by crustal assimilation during magma ascent and emplacement. The lack of across-arc trends in $\mathrm{Ba} / \mathrm{La}$ and other LIL/HFS element ratios argues against a strong influence from the sub-arc mantle and slab, whereas the available data from basement exposures in the region do show E-W differences in composition. We therefore concur with earlier studies of ignimbrite compositions from north of $24{ }^{\circ} \mathrm{S}$ that subtle E-W differences in magma composition reflect the crustal component (Coira et al., 1993; Kay and Coira, 2004). Lucassen et al. (2001) calculated average rock compositions for felsic gneisses from Argentina and Chile, and their results showed higher average $\mathrm{Nb}$ concentrations (15 ppm vs. 9 ppm), as well as more radiogenic $\mathrm{Sr}$ and $\mathrm{Pb}$ and less radiogenic $\mathrm{Nd}$ isotope ratios, in the samples from Argentina. These differences can, at first sight, be attributed to a greater proportion of metasedimentary protoliths in the Argentina basement vs. farther west (Franz et al., 2006 and references therein). However, this interpretation is not straightforward because there is little known about crustal ages and lithologies in the mid and lower crust where assimilation by arc magmas took place, and where the extreme horizontal shortening and thickening in the Miocene will have complicated any pre-Mesozoic arrangement of crustal domains. Finally, an important contributing factor to across-arc crustal variations may be the arc activity itself (Feeley, 1993; Kay and Coira, 2004). The Cenozoic volcanic arc has been more vigorous and more continuous in the western Cordillera of Chile than farther east, with the net effect being a greater modification of the crust by addition of mafic intrusions and by the removal or dilution of lithophile trace elements and easily fusible components in the Chilean crust.

\subsection{Source constraints and the importance of differentiation vs. crustal assimilation}

The origin and evolution of silicic magma systems in volcanic arcs is of current interest because of their relevance to question of crustal growth vs. recycling at active 
margins (e.g., Hildreth, 1981; Johnson, 1991; Smith et al., 1996; Guffanti et al., 1996; Vogel et al., 2004). The key distinction to be made in the CVZ and other continental settings is between melting of older crust (recycling) and differentiation processes from mafic magmas generated in the mantle (net growth). An obviously important second-order process, especially in the thick crust of the $\mathrm{CVZ}$, is the assimilation of crust during magma differentiation. Richards et al. (2006) argued for a mixed fractionation and assimilation scenario for the silicic ignimbrite magmas associated with the Antofalla volcanic complex in the area of this study (Fig. 2), and they proposed that the degree of crustal assimilation decreased with time as the system matured. The chemical variation in the southern CVZ ignimbrites from our study, which reach very high silica values and show differentiation trends following those of associated andesite-dacites (Fig. 5), indicate a major but not exclusive role of fractional crystallization in magma evolution (Siebel et al., 2001; Schnurr, 2002). However, it is clear from the radiogenic isotope data (Fig. 8) that there is a significant crustal component in the silicic magmas as well. The relative importance of differentiation vs. assimilation in the southern CVZ silicic and intermediate magmas is illustrated on Figure 11, which compares chemical differentiation indices (e.g., $\mathrm{Rb} / \mathrm{Sr}$ or $\mathrm{Eu} / \mathrm{Eu}^{*}$ ) with the ${ }^{87} \mathrm{Sr} /{ }^{86} \mathrm{Sr}$ initial ratio. The andesite-dacite data (circles) show variable but significant increases in the $\mathrm{Sr}$ initial ratio with differentiation as expected for combined assimilation and fractionation (AFC) processes. This is a common feature of arc magmas in the CVZ and has been noted many times before (e.g., Davidson et al., 1991). However, an interesting observation here is that samples from Chile (filled circles) and from Argentina (open circles) define different AFC trends, as highlighted on Figure 11 by the qualitative arrows AFC1 and AFC2. The AFC2 trend describes a strong isotopic shift with differentiation and it extends toward the composition of the crustal-dominated Galán and APVC ignimbrites. The AFC1 trend, typical for Chilean localities, involves much less isotopic shift with differentiation, and nearly all of the silicic ignimbrites, regardless of their location in Chile or Argentina, show this behavior.

We conclude from these relationships that the silicic magmas of southern $\mathrm{CVZ}$ ignimbrites formed mainly by differentiation of andesite-dacite magmas that already contained a significant crustal component, and that magma evolution from intermediate to silicic compositions took place with only minor further assimilation of crust. We suggest that the weak assimilation of crust during differentiation to rhyolite may be due to this stage of magma evolution taking place at a shallow level in the crust where assimilation is thermally ineffective. This is consistent with differences in the REE compositions (Fig. 6b), whereby 
the andesite-dacites show a trend to high $\mathrm{Sm} / \mathrm{Yb}$ ratios suggesting magma evolution in garnetbearing crust whereas the silicic magmas lack this feature. The geochemical arguments for an origin of southern CVZ ignimbrites from intermediate arc magmas find support in geologic map relations and satellite imagery which show that some of the ignimbrite units issued from composite volcanoes (see section 3). The fact that the silicic ignimbrites and andesite-dacite magmas erupted over more or less the same time span of arc activity in the southern CVZ (Fig. 9) also supports a direct relationship between the two associations. It would be simplistic to suggest that all of the 28 ignimbrite units covered in this study share the same source and evolved in the same way. Individual differences in composition exist, and they require more complex genetic models. However, we consider the overall evidence compelling that the silicic ignimbrites from this study are genetically linked with intermediate arc magmas and are distinct in that sense from the large-volume ignimbrites that formed from crustal melting at Cerro Galán and in the APVC region further north.

\subsection{Regional implications}

In principle, the scarcity of crustal ignimbrites in the southern CVZ indicates one of two things: either crustal melting on a large scale did not take place or the magmas so formed were unable to segregate, ascend and erupt. In the APVC region, eruption of the large-volume ignimbrites apparently required a tectonic trigger, as suggested by the "trap-door" geometry of the calderas, their association with transtensional fault zones and the high calculated viscosity of the erupted magmas (Lindsay et al., 2001b; Riller et al., 2001; de Silva et al., 2006). The difference in timing of plateau growth and collapse, and in the strength of the continental foreland between the Altiplano and Puna plateaus, suggest that a compressional tectonic regime in the upper crust persisted longer in the southern CVZ (see section 2.1). By these arguments, eruption of crustal melts in the southern CVZ might be suppressed and Cerro Galán, as the only exception, may owe its fortune to being located on the Archibarca lineament (Richards and Villeneuve, 2002). The possibility that crustal-derived silicic magmas were produced in the study area but did not reach the surface cannot be ruled out, and the kind of geophysical data which might reveal their existence have not been acquired yet south of $25^{\circ} \mathrm{S}$. On the other hand, the geologic record shows that silicic ignimbrites have been abundant and widespread in the southern CVZ throughout the Neogene, an age span during which there were major changes in the tectonic regime and thickness of the crust. This 
suggests that the ability to erupt is not the controlling factor in the relative difference in distribution of crustal ignimbrites from north to south in the CVZ.

We suggest that a more likely explanation for the paucity of crustal ignimbrites in the southern CVZ is that the thermal conditions for widespead crustal melting were not met. Numerical modelling by Babeyko et al. (2002) established that enhanced mantle heat flux was critical for the development of crustal melting at the scale of the APVC, and the study also predicted that a time lag of 5-10 My may be needed for heat transport from the Moho into the middle crust, even with comparatively rapid convection. Two scenarios have been suggested for enhanced mantle heat flux in the CVZ in the Miocene. One is slab steepening with consequent influx of asthenosphere into the mantle wedge (e.g., Coira et al., 1993; Kay et al., 1999), and the other is delamination of lithosphere resulting from high density in the lower crust relative to the mantle because of extreme crustal thickness (Kay and Kay, 1993; Kay et al., 1999; Sobolev et al., 2006). Both of these scenarios may act together and their effects will be enhanced. More important, both scenarios can be expected to affect the southern CVZ at a later time, and less intensely, than farther north, and this may be the key reason for a relative lack of crustal melting in the southern CVZ. There is a general consensus that in the central CVZ, a magmatic gap in the Oligocene and broad distribution of arc volcanism in the late Oligocene/early Miocene indicates a shallow dip of the subducting plate at that time (Isacks, 1988; Coira et al., 1993; Kay et al., 1999). The subsequently more vigorous and narrower volcanic arc in the late Miocene and Pliocene, and its shift in position to the western Cordillera where volcanism is now active, suggests that the subduction angle had steepened to a similar value as observed today. The situation in the southern CVZ is quite different. Our study area is close to the "flat-slab" segment of the $\operatorname{arc}\left(28^{\circ} \mathrm{S}\right.$ to $\left.33^{\circ} \mathrm{S}\right)$ which Kay and Abruzzi (1996) suggest to have been established at about 6 Ma based on the cessation of arc magmatism in the region at that time. Therefore, if the process of slab steepening is important for enhancing mantle heat flux and triggering crustal melting, it will be less effective in the southern CVZ than in the arc segment farther north. The same is true for the scenario of lithospheric delamination as a consequence of crustal thickening and high-pressure phase transitions in the lower crust. The fact that the timing of horizontal shortening and plateau growth in the Central Andes progressed from north to south (e.g. Allmendinger et al., 1997; Riller and Oncken, 2003) implies that delamination may follow the same pattern. It is significant in this respect that recent seismic tomography studies (Koulakov et al., 2006; Heit, 2005) indicate higher upper mantle temperatures today beneath the Puna plateau than beneath 
the Altiplano and the APVC. The main phase of ignimbrite eruption from Cerro Galán was at $2 \mathrm{Ma}$, considerably younger than any of the large APVC eruptions (ca. $8-4 \mathrm{Ma}$, de Silva et al., 2006). One might speculate from this that the thermal conditions for crustal melting in the southern plateau region are just being established and that the Galán ignimbrites herald the beginning of a new ignimbrite flare-up.

\section{Conclusions}

This geochemical survey of Neogene silicic ignimbrites from the southern CVZ covers 28 units representing some 25 million years of volcanic activity. The data demonstrate a strong group similarity among these units. Typical are small eruptive volumes $\left(<10 \mathrm{~km}^{3}\right)$ of mainly crystal-poor, metaluminous rhyolitic compositions (average $\mathrm{SiO}_{2}=73.5$ wt.\%, $\mathrm{n}=$ 236). The $\mathrm{Sr}, \mathrm{Nd}$ and $\mathrm{Pb}$ isotopic compositions of the southern $\mathrm{CVZ}$ ignimbrites overlap completely with those of contemporary andesite-dacite volcanic centers, suggesting an origin of the silicic magmas by differentiation of intermediate arc magma. This is supported by a correspondence of trace element variation trends from the two volcanic associations and by the fact that they have a similar distribution in time and space in the southern CVZ. There are no systematic differences in ignimbrite compositions with age over the long span of volcanic activity in this segment of the arc. Minor but significant trace element and radiogenic isotopic variations from west to east (higher $\mathrm{Nb}$ and $\mathrm{Ta}$ concentrations, more radiogenic $\mathrm{Sr}$ and $\mathrm{Pb}$ isotope ratios and less radiogenic $\mathrm{Nd}$ in the east) reflect variations in the local basement composition and/or age structure.

The results of this study and previous work on ignimbrites in the CVZ lead to the conclusion that two types of silicic magma formed during the Neogene development of the central Andes. The small-volume rhyolitic ignimbrites typical for the southern CVZ represent differentiation of intermediate arc magmas and these are widely distributed in space and time. In contrast, the large-volume ignimbrite magmas erupted from caldera complexes like those of the Altiplano-Puna Volcanic Complex and Cerro Galán are of mainly crustal origin and their distribution is characterized by locally extreme "flare-ups" caused by episodes of enhanced mantle heat flux and thermal convection into and within the crust (deSilva et al., 2006). 


\section{Acknowledgements}

This work was carried out in the framework of the Collaborative Research Center (SFB) 267 supported by the Deutsche ForschungsGemeinschaft (DFG). Thanks to Elmar Reitter in Tübingen and to Gerhard Berger, Erika Kramer, Heike Rothe and Rudolf Naumann at GFZ for their skilled technical assistance. Raul Becchio and Raul Seggiaro are thanked for an open-file version of the Antofalla geologic map. They, and Friedrich Lucassen, Pablo Caffe, Jan Lindsay, Axel Schmitt, Shan deSilva, Sue Kay, Betty Coira and Jose Viramonte have provided stimulating discussions on CVZ volcanism both in and outside the field. Journal reviews by Michael Ort and an anonymous colleague led to substantial improvement of the paper.

\section{References}

Aitcheson, S.J. Harmon, R.S., Moorbath, S., Schneider, A., Soler, P., Soria-Escalante, E., Steele, G., Swainbank, I., 1995. Pb isotopes defines basement domains of the Altiplano, central Andes. Geology, 23: 555-558.

Allmendinger, R.W., Jordan, T.E., Kay, S.M., Isacks, B.L., 1997. The evolution of the Altiplano-Puna plateau of the Central Andes. Annual Reviews in Earth and Planetary Science Letters, 25: 139-174.

Arnosio, J.M., 2002. Volcanology, geochemistry and petrology of the Chimpa volcano $\left(24^{\circ} \mathrm{S}\right.$, $\left.66^{\circ} \mathrm{W}\right)$, Provincia de Salta, Republica Argentina. Ph.D. Thesis, Universidad Nacional de Salta, Argentina. 139 pp. (in Spanish)

Babeyko, A.Y., Sobolev, S.V., Trumbull, R.B., Oncken, O., Lavier, L., 2002. Numerical models of crustal scale convection and partial melting beneath the Altiplano-Puna plateau. Earth and Planetary Science Letters, 199: 373-388.

Baker, M.C.W., 1977. Geochronology of the Upper Tertiary volcanic activity in the Andes of N. Chile. Geologische Rundschau, 66: 455-475.

Becchio, R., Lucassen, F., Franz, G., Viramonte, J., Wemmer, K., 1999. The lower Paleozoic basement in NW Argentina $\left(23^{\circ}-27^{\circ} \mathrm{S}\right)$ - metamorphism and geochronology. Actas del Congreso Geologico Argentino, 14, I: 58-72 (in Spanish).

Blundy, J.D., Wood, B.J., 1991. Crystal-chemical controls on the partitioning of Sr and Ba between plagioclase feldspar, silicate melts and hydrothermal solutions. Geochimica et Cosmochimica Acta, 55: 193-209.

Brasse, H., Lezaeta, P., Rath, V., Schwalenberg, K., Soyer, W., Haak, V., 2002. The Bolivian Altiplano conductivity anomaly. Journal of Geophysical Research, 107: 10.1029/2001JB000391.

Cahill, T., Isacks, B.L., 1992. Seismicity and shape of the subducted Nazca plate. Journal of Geophysical Research, 97 (B12): 17503-17529.

Chmielowski, J., Zandt, G., Haberland, C., 1999. The Central Andean Altiplano-Puna magma body. Geophysical Research Letters, 26: 783-786.

Clavero, J., Gardeweg, M., Mpodozis, C., 2006a Geology of the region Salar de Piedra Parada, III Región de Atacama, Chile, 1:100.000. Servicio Nacional de Geología y Minería, Santiago de Chile (in Spanish). 
Clavero, J., Mpodozis, C., Gardeweg, M., 2006b. Geology of the region Salar de Wheelwright, III Región de Atacama, Chile, 1:100.000. Servicio Nacional de Geología y Minería, Santiago de Chile (in Spanish).

Coira, B., Kay, S.M., 1993. Implications of Pleistocene volcanism at Cerro Tuzgle for crustal and mantle evolution of the Puna Plateau, Central Andes, Argentina. Contributions to Mineralogy and Petrology, 113, 40-56.

Coira, B., Kay, S.M., 1999. Cenozoic volcanic evolution of the region Agua Escondida-Salar de Aguas Calientes - Southern Puna (Central Andes 25³0’S). XIV Congreso Geológico Argentino, Salta, p. 90. (in Spanish)

Coira, B., Kay, S.M., 2004. Central Andean Plateau ignimbrites in the Puna Back-arc Cenozoic Volcanic Province (PBCV). IAVCEI 2004 General Assembly, 14-19. November, Pucón, Chile (unpaginated abstract).

Coira, B., Caffe, P.J., Kay, S.M., Diaz, A., Ramirez, A., 1996. The Vilama volcanic complex - an upper Cenozoic caldera system in the Puna, Jujuy. Actas del Congreso Geologico Argentino, 13, 3: 603-620 (in Spanish)

Coira, B., Davidson J, Mpodozis, C., Ramos, V., 1982. Tectonic and magmatic evolution of the Andes of Northern Argentina and Chile. Earth Science Reviews, 18: 302-332.

Coira, B., Kay, S.M., Viramonte, J., 1993. Upper Cenozoic magmatic evolution of the Argentine Puna - a model for changing subduction geometry. International Geology Review, 35: 677-720.

Coira, B., Peréz, B., Flores, P., Kay, S.M., Woll, B., Hanning, M., 1999. Magmatic sources and tectonic setting of the Gondwana margin Ordovician magmas, northern Puna of Argentina and Chile. In: Ramos, V.A. and. Keppie, J.D (Eds-) Laurentia-Gondwana Connections before Pangea. Geological Society of America, Special Paper 336, Boulder, pp. 145-170.

Davidson, J.P., Harmon, R.S., Wörner, G., 1991. The source of central Andean magmas; Some considerations. In: Harmon, R.S. and Rapela, C.W. (Eds.), Andean magmatism and its tectonic setting. Geological Society of America, Special Paper 265, Boulder, pp. 233243.

deSilva, S.L., 1989. Altiplano-Puna volcanic complex of the central Andes. Geology, 17: 1102-1106.

deSilva, S.L., 1991. Styles of zoning in central Andean ignimbrites; Insights into magma chamber processes. In: Harmon, R.S. and. Rapela, C.W (Eds.), Andean magmatism and its tectonic setting. Geological Society of America Special Paper 265, Boulder, pp. 217-232.

deSilva, S.L., Zandt, G., Trumbull, R.B., Viramonte J.G., Salas, G., Jimenez, M., 2006. Large-scale silicic volcanism in the Central Andes - a tectonomagmatic perspective. In: Troise, C., deNatale, G., Kilburn, C.R.J. (Eds) Mechanisms of Activity and Unrest at Large Calderas. Geol. Soc. London Special Publication 269, pp. 47-63.

Feeley, T.C., 1993. Crustal modification during subduction -zone magmatism: Evidence from the southern Salar de Uyuni region $\left(20^{\circ}-22^{\circ} \mathrm{S}\right)$, central Andes. Geology, 21: 1019-1022.

Francis, P.W., Sparks, R.S.J., Hawkesworth, C.J., Thorpe, R.S., Pyle, D.M., Tait, S.R., Mantovani, M.S., McDermott, F., 1989. Petrology and geochemistry of volcanic rocks of the Cerro Galán caldera, northwest Argentina. Geological Magazine, 126: 515-547.

Franz, G., Lucassen, Kramer, W., Trumbull, R.B., Romer, R.L., Wilke, H-G., Viramonte, J.B., Becchio, R., Siebel, W., 2006. Crustal evolution at the Central Andean continental margin: a geochemical record of crustal growth, recycling and destruction. In: Oncken, O., Chong, G., Franz, B., Giese, P., Götze, H.-J., Ramos, V.A., Strecker, M.R., Wigger, P. (Eds.), The Andes - Active Subduction Orogeny. Frontiers in Earth Science Series, Springer-Verlag, Berlin, Heidelberg, New York, pp. 45-64. 
Gardeweg, M., Ramírez, C.F., 1987. The La Pacana caldera and the Atana ignimbrite - A major ash-flow and resurgent caldera complex in the Andes of northern Chile. Bulletin of Volcanology 49: 547-566.

Graeber, F., Asch, G., 1999. Three-dimensional models of P wave velocity and P-to S velocity ratio in the southern central Andes by simultaneous inversion of local earthquake data. Journal of Geophysical Research, 104: 20237-20256.

Gregory-Wodzicki, K.M., 2000. Uplift hisory of the Central and Northern Andes: a review. Geological Society of America Bulletin, 112: 1091-1105.

Guffanti, M., Clynne, M.A., Muffler, L.J.P., 1996. Thermal and mass implications of magmatic evolution in the Lassen volcanic region, California, and minimum constraints on basalt influx to the lower crust. Journal of Geophysical Research 101: 3003-3013.

Gutscher, M.A., Spakman, W., Bijwaard, H., Engdahl, E.R., 2000. Geodynamics of flat subduction: Seismicity and tomographic constraints from the Andean margin. Tectonics, 19: 814-833.

Haschke, M., Siebel, W., Günther, A., Scheuber, E., 2002. Repeated crustal thickening and recycling during the Andean orogeny in north Chile $\left(21^{\circ} \mathrm{S}-26^{\circ} \mathrm{S}\right)$. Journal of Geophysical Research, 107: doi: 10.1029/2001JB000328 (ECV 6-1-18).

Heit, B.S., 2005. Teleseismic tomographic images of the Central Andes at $21^{\circ} \mathrm{S}$ and $25.5^{\circ} \mathrm{S}$ : an inside look at the Altiplano and Puna plateaus. GeoForschungsZentrum Potsdam, Scientific Technical Report STR06/05, Potsdam, 139 pp.

Hildreth, W. 1981. Gradients in silicic magma chambers: implications for lithospheric magmatism. Journal of Geophysical Research 86, 10153-10192.

Hildreth, W., Moorbath, S., 1988. Crustal contributions to arc magmatism in the Andes of central Chile. Contributions to Mineralogy and Petrology, 98: 455-489.

Isacks, B.L., 1988. Uplift of the Central Andes Plateau and bending of the Bolivian orocline. Journal of Geophysical Research, 93: 3211-3231.

Johnson, C.M., 1991. Large-scale crust formation and lithospheric modification beneath middle to late Cenozoic calderas and volcanic fields, western north America. Journal of Geophysical Research 96: 13485-13507.

Kasemann, S.A., Erzinger, F., Franz, G., 2000. Boron recycling in the continental crust of the Central Andes from the Palaezoic to Mesozoic, NW Argentina. Contributions to Mineralogy and Petrology, 140: 328-343.

Kay, R.W., Kay, S.M., 1993. Delamination and delamination magmatism. Tectonophysics, 219: 177-189.

Kay, S.M., Abruzzi, J., 1996. Magmatic evidence for Neogene lithospheric evolution of central Andean 'flat slab' between $30^{\circ} \mathrm{S}$ and $32^{\circ} \mathrm{S}$. Tectonophysics, 259: 15-28.

Kay, S.M., Coira, B., Viramonte, J., 1994a. Young mafic back arc volcanic rocks as indicators of continental lithospheric delamination beneath the Argentine Puna plateau, Central Andes. Journal of Geophysical Research, 99: 24323-24339.

Kay, S.M., Mpodizis, C., Tittler, A., Cornejo, P., 1994b. Tertiary magmatic evolution of the Maricunga mineral belt in Chile. International Geology Review, 36: 1079-1112.

Kay, S.M., Mpodozis, C., 2002. Magmatism as a probe to the Neogene shallowing of the Nazca plate beneath the modern Chilean flat-slabs. Journal of South American Earth Sciences, 15: 39-57.

Kay, S.M., Mpodozis, C., Coira, B., 1999. Neogene magmatism, tectonism, and mineral deposits of the Central Andes (22 degrees to 33 degrees S latitude). In: J. Skinner Brian (Editor), Geology and ore deposits of the Central Andes. Special Publication - Society of Economic Geologists, pp. 27-59.

Kley, J., Monaldi, C.R., Salfity, J.A., 1999. Along-strike segmentation of the Andean foreland: causes and consequences. Tectonophysics, 301: 75-94. 
Koulakov, I., Sobolev, S.V., Asch, G., 2006. P- and S-velocity images of the lithosphereasthenosphere system in the Central Andes from local-source tomographic inversion. Geophysical Journal International, 167: 106-126.

Kraemer, B. Adelmann, D., Alten, M., Schnurr, W., Erpenstein, K., Kiefer, E., van den Bogaard, P., Görler, K., 1999. Incorporation of the Paleogene foreland into the Neogene Puna Plateau; the Salar de Antofalla area, NW Argentina. Journal of South American Earth Sciences, 12: 157-182.

Lindsay, J.M., de Silva, S., Trumbull, R., Emmermann, R., Wemmer, K., 2001a. La Pacana caldera, N. Chile: a re-evaluation of the stratigraphy and volcanology of one of the world's largest resurgent calderas. Journal of Volcanology and Geothermal Research, 106: 145173.

Lindsay, J.M., Schmitt, A.K., Trumbull, R.B., de Silva, S.L., Siebel, W., Emmermann, R, 2001b. Magmatic evolution of the La Pacana Caldera system, Central Andes, Chile: compositional variation of two cogenetic, large-volume felsic ignimbrites and implications for contrasting eruption mechanisms. Journal of Petrology, 42: 459-486.

Lucassen, F. Becchio, R., Harmon, R., Kasemann, S., Franz, G., Trumbull, R., Romer, R.L., Dulski, P., 2001. Composition and density model of the continental crust at an active continental margin - the Central Andes between $21^{\circ}$ and $27^{\circ} \mathrm{S}$. Tectonophysics, 341: 195223.

Lucassen, F., Franz, G., 2005. The early Palaeozoic orogen in the Central Andes: a noncollisional orogen comparable to the Cenozoic high plateau? In: Faughan, A.P.M., Leat, P.T., Pankhurst, R.J. (Eds.) Terrane Processes at the Margins of Gondwana. Geological Society of London Special Publications, 246: 257-273.

Lucassen, F., Franz, G., Thirlwall, M.F., Mezger, K., 1999. Crustal recycling of metamorphic basement: Late Palaeozoic granitoids of northern Chile $\left(\sim 22^{\circ} \mathrm{S}\right)$. Implications for the composition of the Andean Crust. Journal of Petrology, 40: 1527-1551.

Mason, B.G., Pyle, D.M., Oppenheimer, C., 2004. The size and frequency of the largest explosive eruptions on Earth. Bull. Volcanology 66: 735-748.

Marrett, R.A., Allmendinger, R.W., Alonso, R.N., Drake, R.E., 1994. Late Cenozoic tectonic evolution of the Puna Plateau and adjacent foreland, northwestern Argentine Andes. Journal of South American Earth Sciences, 7: 179-207.

Matteini, M., Mazzuoli, R., Omarini, R., Cas, R., Maas, R., 2002, The geochemical variations of the upper cenozoic volcanism along the Calama-Olacapato-El Toro transversal fault system in central Andes $\left(24^{\circ} \mathrm{S}\right)$ : petrogenetic and geodynamic implications.

Tectonophysics, 345: 211-227.

McDonough, W.F., Sun, S.S., 1995. The composition of the Earth. Chemical Geology, 120: 223-253.

McKee, E.H., Robinson, A.C., Rybuta, J.J., Cuitino, L., Moscoso, R.D., 1994. Age and Srisotopic composition of vlcanic rocks in the Maricunga Belt, Chile: implications for magma sources. Journal of South American Earth Sciences, 7: 167-177.

Naranjo, J., Cornejo, P., 1992. Hoja Salar de la Isla.- Geological Map of Chile, No. 72, 1:250000. Servicio National de Geologia y Mineria, Santiago, Chile (in Spanish).

Oncken, O., Hindle, D., Kley, J., Elger, K., Victor, P., Schemmann, 2006. Deformation of the Central Andean upper plate system - facts, fiction, and constraints for plateau models. In: Oncken, O., Chong, G., Franz, G., Giese, P., Götze, H.-J., Ramos, V.A., Strecker, M.R., Wigger, P. (Eds.), The Andes - Active Subduction Orogeny. Frontiers in Earth Science Series, Springer-Verlag, Berlin, Heidelberg, New York, pp. 3-28.

Ort, M.H., 1993. Eruptive processes and caldera formation in a nested downsag-collapse caldera: Cerro Panizos, Central Andes mountains. Journal of Volcanology and Geothermal Research, 56: 221-252. 
Ort, M., Coira, B.L., Mazzoni, M.M., 1996. Generation of a crust-mantle magma mixture: magma sources and contamination at Cerro Panizos, central Andes. Contributions to Mineralogy and Petrology, 123: 308-322.

Pankurst, R.J., Rapela, C.W., Saavedra, J., Baldo, E., Dahlquist, J., Pascua, I., Fanning, C.M., 1998. The Fatamian magmatic arc in the central Sierras Pampeanas: an early-to-midddle Ordovician continental arc on the Gondwana margin. In: R.J. Pankurst and C.W. Rapela (Eds.), The Proto-Andean Margin of Gondwana. Geological Society of London, Special Publications, pp. 343-367.

Rapela, C.W., Pankhurst, R.J., Casquet, C., Baldo, E., Saavedra, C., Galindo, C., Fanning, C.M., 1998. The Pampean Orogeny of the southern proto-Andes: evidence for Cambrian continental collision in the Sierras de Córdoba. In: R.J. Pankhurst and C.W. Rapela (Eds), The Proto-Andean Margin of Gondwana. Geological Society of London, Special Publications, pp. 181-217.

Richards, J.P., Villeneuve, M., 2002. Characteristics of the late Cenozoic volcanism along the Archibarca lineament from Cerro Llullaillaco to Corrida de Cori, northwest Argentina. Journal of Volcanology and Geothermal Research, 116: 161-200.

Richards, J.P., Ullrich, T., Kerrich, R., 2006. The Late Miocene-Quaternary Antofalla volcanic complex, southern Puna, NW Argentina: Protracted history, diverse petrology, and economic potential. Journal of Volcanology and Geothermal Research, 152: 197-239.

Riller, U., Oncken, O., 2003. Growth of the Central Andean Plateau by tectonic segmentation is controlled by the gradient in crustal shortening. Journal of Geology, 111: 367-384.

Riller, U., Petrinovich, I., Ramelow, J., Strecker, M., Oncken, O., 2001. Late Cenozoic tectonism, collapse caldera and plateau formation in the Central Andes. Earth and Planetary Science Letters, 188: 299-311.

Salfity, J.A., 1985. Transverse lineaments along the Andes in NW Argentina. Actas del 4. Congreso Geologico Chileno, 2: A119-A127 (in Spanish).

Schilling, F.R., Trumbull, R.B., Brasse, H., Haberland, C., Asch, G., Bruhn, D , Haak, V., Giese, P., Mai, K., Munoz, M., Ramelow, J., Rietbrock, A., Ricaldi, E., Vietor, T., 2006. Partial Melting in the Central Andean Crust, A Review of Geophysical, Petrophysical, and Petrologic Evidence. In: Oncken, O., Chong, G., Franz, G., Giese, P., Götze, H.-J., Ramos, V.A., Strecker, M.R., Wigger, P. (Eds.), The Andes - Active Subduction Orogeny. Frontiers in Earth Science Series, Springer-Verlag, Berlin, Heidelberg, New York, pp. 460-474.

Schmitt, A.K., de Silva, S.L., Trumbull, R.B., Emmermann, R., 2001. Magma evolution in the Purico ignimbrite complex, northern Chile: evidence for zoning of a dacitic magma by injection of rhyolitic melts following mafic recharge. Contributions to Mineralogy and Petrology, 140: 680-700.

Schmitt, A.K., Lindsay, J.M., deSilva, S., Trumbull, R.B., 2002. U-Pb zircon chronostratigraphy of early-Pliocene ignimbrites from La Pacana, north Chile: implications for the formation of stratified magma chambers. Journal of Volcanogy and Geothermal Research, 120: 43-53.

Schnurr, W., 2002. On the geochemistry and genesis of Neogene and Quaternary felsic volcanic rocks in the southern Central Andes $\left(25^{\circ}-27^{\circ} \mathrm{S}\right.$ und $\left.67^{\circ}-69^{\circ} \mathrm{W}\right)$. Berliner Geowissenschaftliche Abhandlungen, 211. Selbstverlag Fachbereich Geowissenschaften, Freie Universität Berlin, Berlin, 152 pp. (in German).

Schnurr, W.B.W., Risse, A., Trumbull, R.B, Munier, K., 2006. Digital Geological Map of the Southern and Central Puna Plateau, NW Argentina. In: Oncken, O., Chong, G., Franz, G., Giese, P., Götze, H.-J., Ramos, V.A., Strecker, M.R., Wigger, P. (Eds) The Andes - Active Subduction Orogeny. Frontiers in Earth Science Series, Springer-Verlag, Berlin, Heidelberg, New York, pp. 563-564. 
Seggiaro, R., 1994. Petrology, geochemistry and eruption mechanism of the Coranzuli volcanic complex. Ph.D. Thesis, Universidad Nacional de Salta, 150 pp (in Spanish)

Seggiaro, R.E. and Hongn, F.D., 1999. Tectonic influence on the Cenozoic volcanism in NW Argentina. Acta Geologica Hispanica, 34: 227-242 (in Spanish).

Seggiaro, R.E. and Hongn, F.D., 2003. Geological Map 2967-II, Paso de San Francisco. 1:250,000 Servicio Geológico Minero Argentino, Buenos Aires (in Spanish).

Seggiaro, R.E., Becchio, R., Schnurr, W., Adelmann, D. and Erpenstein, K. 2006, Geological Map 2569-IV, Antofalla, 1:250,000. Servicio Geológico Minero Argentino, Buenos Aires (in Spanish).

Siebel, W., Schnurr, W.B.W., Hahne, K., Kraemer, B., Trumbull, R.B., van den Bogaard, P., Emmermann, R., 2001. Geochemistry and isotope systematics of small- to medium-volume Neogene-Pleistocene ignimbrites in the southern central Andes: evidence for derivation from andesitic magma sources. Chemical Geology, 171: 213-237.

Sisson, T.W., Ratajeski, K., Hankins, W.B., Glazner, A.F., 2005. Voluminous granitic magmas from common basaltic sources. Contributions to Mineralogy and Petrology, 148: 635-661.

Smith, R.D., Cameron, K.L., McDowell, F.W., Niemeyer, S., Sampson, D.E., 1996. Generation of voluminous silicic magmas and formation of mid-Cenozoic crust beneath north-central Mexico: evidence from ignimbrites, associated lavas, deep crustal granulites and mantle pyroxenites. Contribution to Mineralogy and Petrology, 123: 375-389.

Sobolev, S.V., Babeyko, A.Y., Koulakov, I., Oncken, O. (2006) Mechanism of the Andean orogeny: insight from numerical modelling. In: Oncken, O., Chong, G., Franz, G., Giese, P., Götze, H.-J., Ramos, V.A., Strecker, M.R, Wigger, P. (Eds) The Andes - Active Subduction Orogeny. Frontiers in Earth Science Series, Springer-Verlag, Berlin, Heidelberg, New York, pp. 513-535.

Sparks, R.S.J., Francis, P.W., Hamer, R.D., Pankhurst, R.J., O’Callaghan, L.O., Thorpe, R.S., Page, R.N., 1985. Ignimbrites of the Cerro Galán Caldera, NW Argentina. Journal of Volcanology and Geothermal Research, 24: 205-248.

Thorpe, R.S., Francis, P.W., 1979. Variations in Andean andesite compositions and their petrogenetic significance. Tectonophysics, 57: 53-70.

Trumbull, R.B., Wittenbrink, R, Hahne, K., Emmermann, R., Büsch,. W., Gerstenberger, H., Siebel, W., 1999. Evidence for Late Miocene to Recent contamination of arc andesites by crustal melts in the Chilean Andes $\left(25-26^{\circ} \mathrm{S}\right)$ and its geochemical implications. Journal of South American Earth Sciences, 12: 135-155.

Trumbull, R.B., Riller, U., Oncken, O., Scheuber, E., Munier, K., Hongn, F., 2006. The timespace distribution of Cenozoic arc volcanism in the Central Andes: a new data compilation and some tectonic considerations. In: Oncken, O., Chong, G., Franz, G., Giese, P., Götze, H.-J., Ramos, V.A., Strecker, M.R, Wigger, P. (Eds) The Andes - Active Subduction Orogeny. Frontiers in Earth Science Series, Springer-Verlag, Berlin, Heidelberg, New York, pp. 29-43.

Vogel, T.A., Patino, L.C., Alvarado, G.E., Gans, P.B., 2004. Silicic ignimbrites within the Costa Rican volcanic front: evidence for the formation of continental crust. Earth and Planetary Science Letters, 226: 149-159.

Walker, J.A., Moulds, T.N., Zentilli, M., Feigenson, M.D., 1991. Spatial and temporal variations in volcanics of the Andean Central Volcanic Zone (26 to $\left.28^{\circ} \mathrm{S}\right)$. In:. Harmon, R.S and Rapela, C.W. (Eds.) Andean magmatism and its tectonic setting. Geological Society of America Special Paper 265, pp. 139-155.

Whitman, D., Isacks, B.L., Chalelain, J.L., Chiu, J.M., Perez, A., 1992. Attenuation of highfrequency seismic waves beneath the Central Andean Plateau. Journal of Geophysical Research, 97: 19929-19947. 
Wörner, G., Moorbath, S., Harmon, R.S., 1992. Andean Cenozoic volcanic centers reflect basement isotopic domains. Geology, 20: 1103-1106.

Yuan, X., Sobolev, S.V., Kind, R., 2002. Moho topography in the central Andes and its geodynamic implication. Earth and Planetary Science Letters, 199: 389-402.

Yuan, X. Sobolev, S., Kind, R., Oncken, O., Bock, G., Asch, B., Schurr, B., Graeber, F., Rudloff, A., Hanka, W., Wylegalla, K., Tibi, R., Haberland, C., Rietbrock, A., Giese, P., Wigger, P., Roewer, P., Zandt, G., Beck, S, Wallace, T., Pardo, M., Compte, D., 2000. Subduction and collision processes in the Central Andes constrained by converted seismic phases. Nature, 408: 958-961.

Zandt, G., Leidig, M., Chmielowski, J., Baumont, D., Yuan, X., 2003. Seismic detection and characterization of the Altiplano-Puna magma body, Central Andes. Pure and Applied Geophysics, 160: 789-807. 


\section{Figure captions}

Figure 1. Regional sketch map of the Central Andes showing the distribution of Neogene ignimbrites and calderas along with the recent volcanic chain and localities discussed in the text. The inset shows approximate location of NW-SE transcurrent lineament zones from Salfity (1985), labelled as follows: L- Lipez, COT-Calama-Olacapato-El Toro, AArchibarca, C-Culampaja.

Figure 2. Location map of the study area in the southern CVZ modified from Siebel et al. (2001) and Schnurr et al. (2006), showing the distribution of ignimbrites and approximate locations of the units sampled for this study. See data tables for precise sample coordinates.

Figure 3. (a) Whole-rock variations of $\mathrm{SiO}_{2}$ vs. $\mathrm{K}_{2} \mathrm{O} / \mathrm{Na}_{2} \mathrm{O}$ ratio of southern $\mathrm{CVZ}$ ignimbrites grouped according to age. Samples with $>4$ wt. $\% \mathrm{H}_{2} \mathrm{O}$ and $>0.5$ wt. $\% \mathrm{CO}_{2}$ are chemically altered and not shown (see text). The La Ola ignimbrite is singled out as the only andesitic unit in the data set (see text). Also shown are data from ignimbrites from the Cerro Galán complex (Galán, Merihuaca and Real ignimbrites; data from Francis et al., 1989).

(b) Frequency histogram of whole-rock $\mathrm{SiO}_{2}$ concentrations in southern $\mathrm{CVZ}$ ignimbrites showing the dominance of rhyolitic compositions among them. (c) Frequency histogram of the $\mathrm{A} / \mathrm{CNK}$ ratio (molar ratio $\mathrm{Al}_{2} \mathrm{O}_{3} / \mathrm{CaO}+\mathrm{Na}_{2} \mathrm{O}+\mathrm{K}_{2} \mathrm{O}$ ), showing the dominance of metaluminous compositions.

Figure 4. Variation diagram of $\mathrm{SiO}_{2}$ and $\mathrm{K}_{2} \mathrm{O}$ showing individual composition ranges in each of the 28 ignimbrite units analyzed for this study, with "zoned" vs. "homogeneous units listed together with number of samples analyzed. The lines for "zoned ignimbrites" are linear regressions with the symbols (numbered circles) plotted at the low-silica end. The black dashed line represents the trend defined by contemporary andesite-dacite centers based on linear regression of 154 samples $(r=0.7)$ from data in Trumbull et al. (1999), Kraemer et al. (1999), and additional analyses from this study.

Figure 5. (a-f) Selected major and trace element variation diagrams showing whole-rock compositions of southern CVZ ignimbrites, using total $\mathrm{Fe}$ as $\mathrm{Fe}_{2} \mathrm{O}_{3}$ as an index of differentiation. Stars on a shaded field represent data from ignimbrites of the Cerro Galán complex (data from Francis et al., 1989). The black dashed line in each plot represents the variation trend defined by contemporary andesite-dacite centers as in Fig. 4. Note the kinked trends for $\mathrm{Zr}$ and to a lesser extent, Ba suggest a two-stage fractionation (see text), and the deviations of some units from the group trends, particularly in Ba and Rb plots.

Figure 6 (a) Whole-rock variations of $\mathrm{Sr}$ and the Eu/Eu* ratio in the southern $\mathrm{CVZ}$ ignimbrites. The data define a linear correlation which parallels that of contemporary andesite-dacites (dashed line) until an inflection at about $150 \mathrm{ppm} \mathrm{Sr}$, which is interpreted to reflect the onset of sanidine crystallization (see text).

(b) Variations in rare earth element ratios within the southern CVZ ignimbrites compared with data for large-volume ignimbrites from Cerro Galán and from the APVC (Panizos, Toconao and Atana), and with contemporary andesite-dacite centers (shaded field). Data sources: Francis et al. (1989), Ort et al. (1996), Lindsay et al. (2001b), Trumbull et al. (1999), Kraemer et al. (1999). See text for explanations.

Figure 7. Chondrite-normalized (McDonough and Sun, 1995) REE abundances in the southern CVZ ignimbrites (open symbols). Typical for these rocks are the convexupward patterns which we attribute to removal of mid-REE by hornblende fractionation. The most differentiated units have prominent negative Eu anomalies and low LREE (bottom left and right plots). The Cerro Galán ignimbrites (filled stars, upper left plot) have steep REE patterns and high $\mathrm{Sm} / \mathrm{Yb}$ ratios (compare Fig. 6b). 
Figure 8. (a, b). Isotopic compositions of $\mathrm{Sr}, \mathrm{Nd}$ and $\mathrm{Pb}$ for the southern $\mathrm{CVZ}$ ignimbrites from this study (open symbols keyed to age) compared with the contemporary andesitedacite centers (data from Trumbull et al., 1999; Kraemer et al.,1999; and Table 4), and with large-volume ignimbrites from Cerro Galán (stars), and the APVC (ruled fields). For data sources see caption to Fig. 6.

Figure 9. Plots of age vs. isotopic composition for the southern CVZ ignimbrites and associated arc andesite-dacites, divided by locations in Chile (W. Cordillera) and Argentina (Puna).

Figure $10 \mathrm{a}, \mathrm{b}$. Comparison of incompatible trace element contents and ratios for southern CVZ silicic ignimbrites and associated arc andesite-dacites from Chile vs. Argentina localities. Neither volcanic association shows a consistent difference in $\mathrm{Ba} / \mathrm{La}$ or $\mathrm{Ta} / \mathrm{La}$ ratios with E-W position, and most other chemical variables are also independent of location. The exceptions are $\mathrm{Nb}$ and $\mathrm{Ta}(10 \mathrm{~b})$ which are higher in ignimbrites and andesite-dacites from Argentina than in Chile.

Figure 11. Plots of differentiation indices $\mathrm{Rb} / \mathrm{Sr}$ and $\mathrm{Eu} / \mathrm{Eu}^{*}$ against the initial ${ }^{87} \mathrm{Sr} /{ }^{86} \mathrm{Sr}$ ratio in the southern CVZ ignimbrites and andesite-dacite volcanics, illustrating the relative roles of crustal assimilation versus fractionation in magma evolution. The andesite-dacite data (filled and open circles) show different data trends depending on E-W location. These trends are highlighted by arrows AFC1 and AFC2 (qualitative, not modelled, see text). The silicic ignimbrites overlap AFC1 trend, consistent with fractionation and minor crustal assimilation. The crustal-dominated ignimbrites from Galán (stars) and the APVC (ruled fields) plot at the extension of the AFC2 trend (data sources as in Fig. 6). 


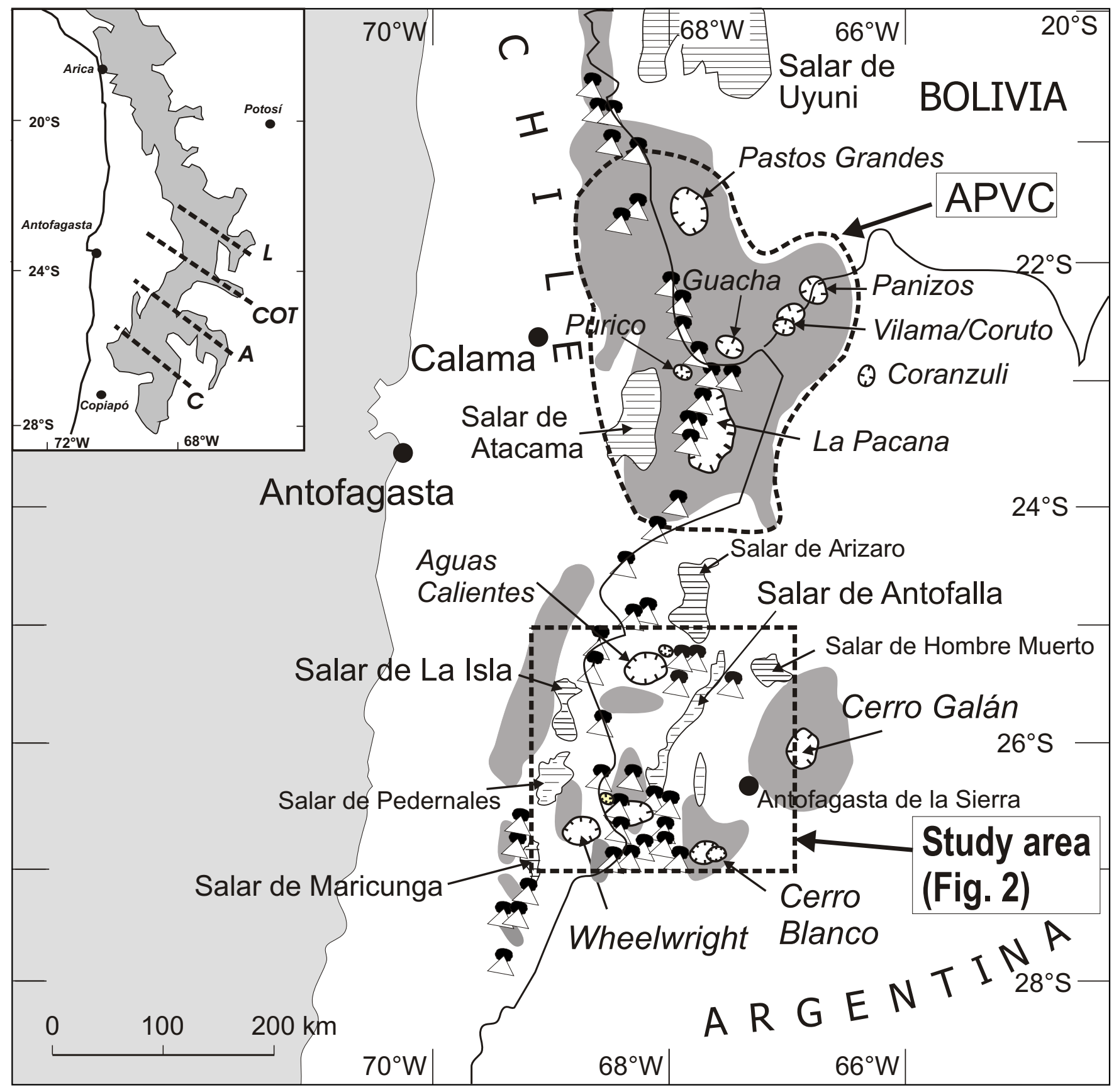

Early Miocene to Pliocene felsic ignimbrite deposits

i) Caldera

$\checkmark$ Pleistocene andesitic-dacitic stratovolcanoes (main arc)

Schnurr et al., Fig. 1 


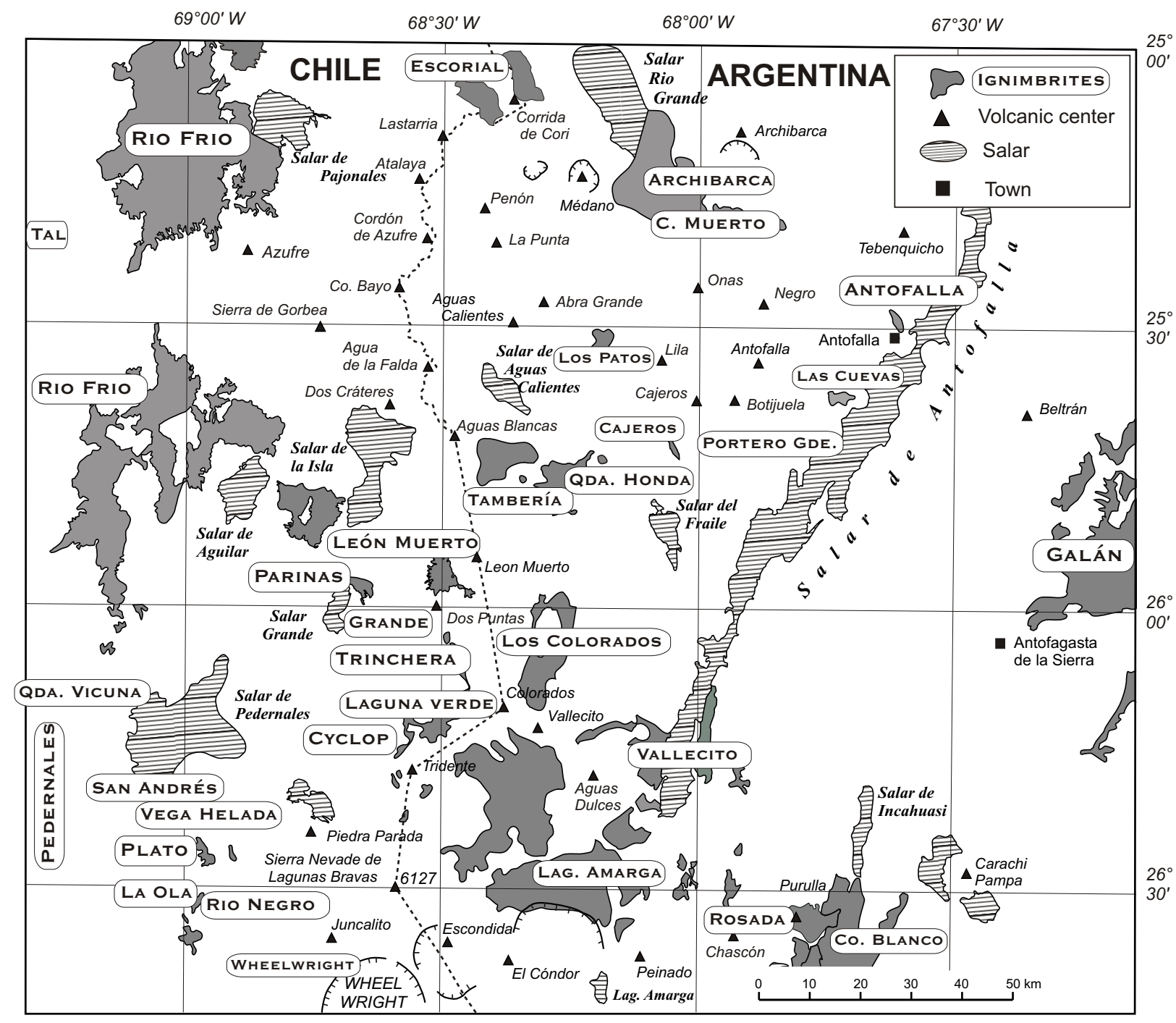

Schnurr et al., Fig. 2 

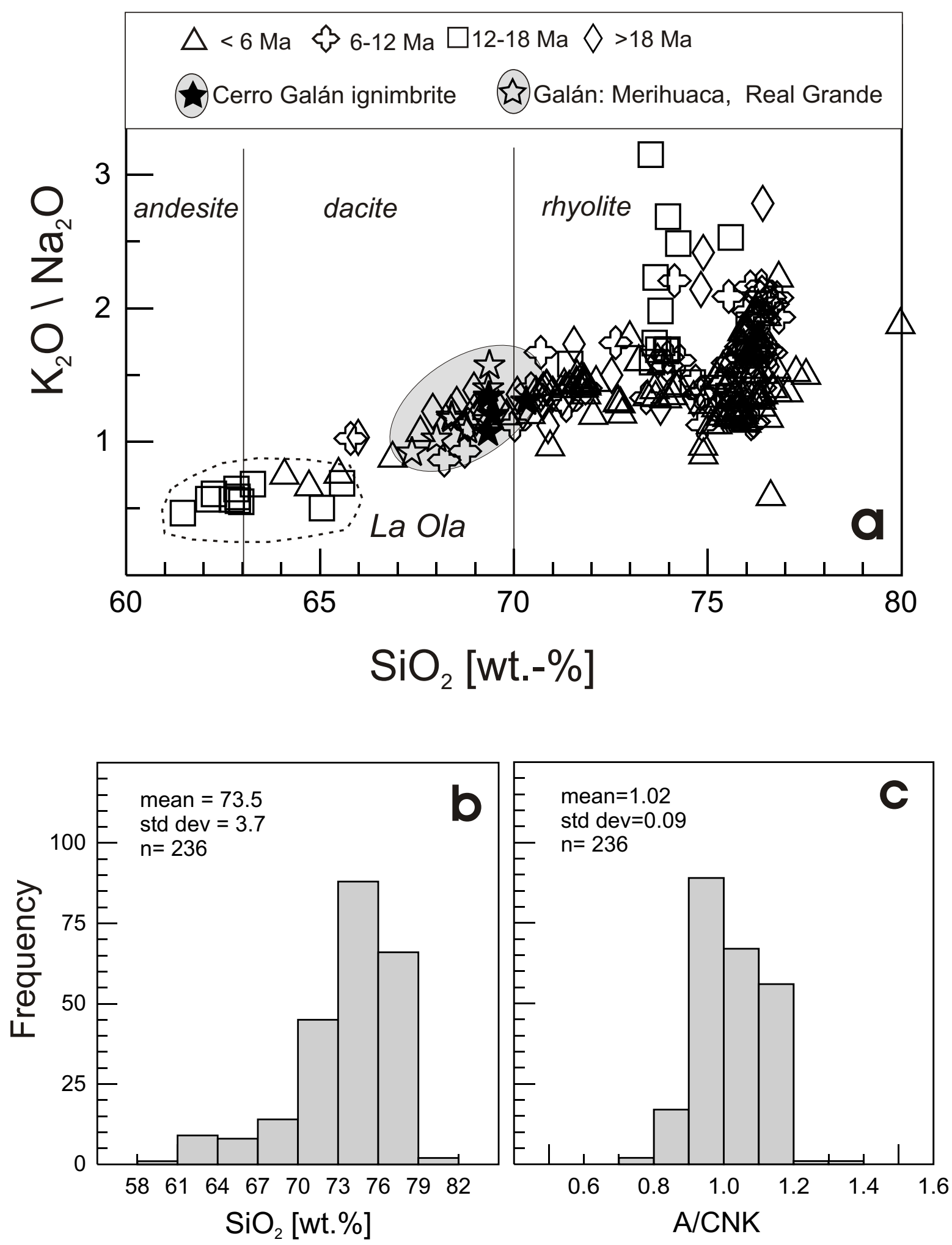

Schnurr et al., Fig. 3 


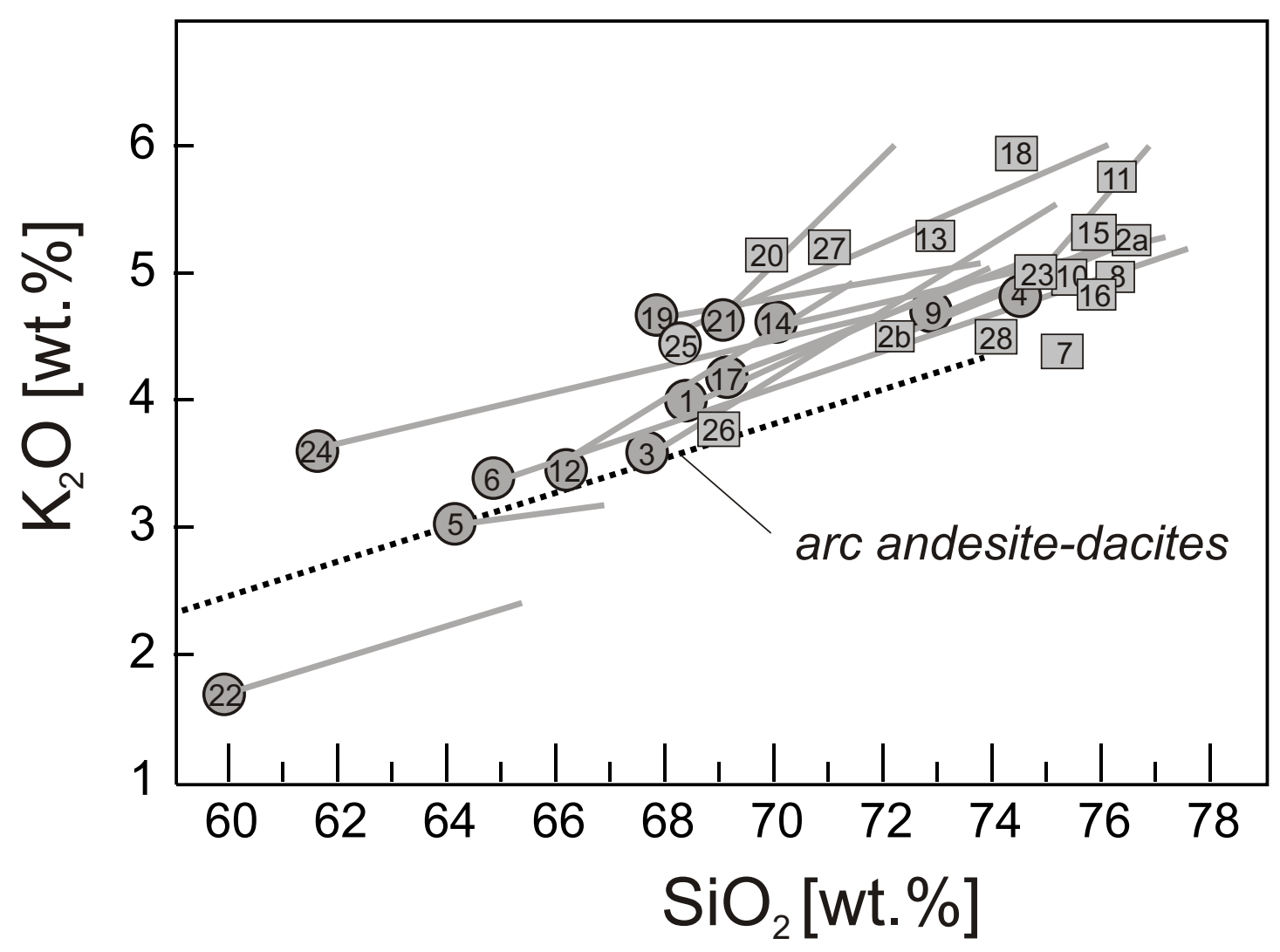

Zoned ignimbrites

1 Cerro Blanco $(n=13)$

3 Caballo Muerto $(n=4)$

4 Vallecito $(n=10)$

5 Wheelwright $(n=2)$

6 Laguna Verde $(n=6)$

9 Laguna Amarga $(n=4)$

12 Rosada $(n=7)$

14 San Andres $(n=2)$

17 Trinchera West $(n=11)$

21 Plato $(n=13)$

22 La Ola $(n=13)$

24 Rio Frio $(n=27)$

25 Tal $(n=8)$ $\underline{\text { Homogeneous ignimbrites }}$

2a Archibarca, lower $(n=35)$

$2 b$ Archibarca, upper $(n=16)$

7 Parinas $(n=37)$

8 Trinchera $(n=10)$

10 Cyclop $(n=3)$

11 Rio Negro $(n=16)$

13 Cajeros $(n=3)$

15 Potrero Grande $(n=6)$

16 Tamberia $(n=7)$

18 Pedernales West $(n=4)$

19 Grande $(n=7)$

20 Antofalla $(n=4)$

23 Quebrada Honda $(n=4)$

26 Leon Muerto $(n=1)$

27 Qda. Vicuna $(\mathrm{n}=2)$

28 Los Colorados $(n=2)$ 


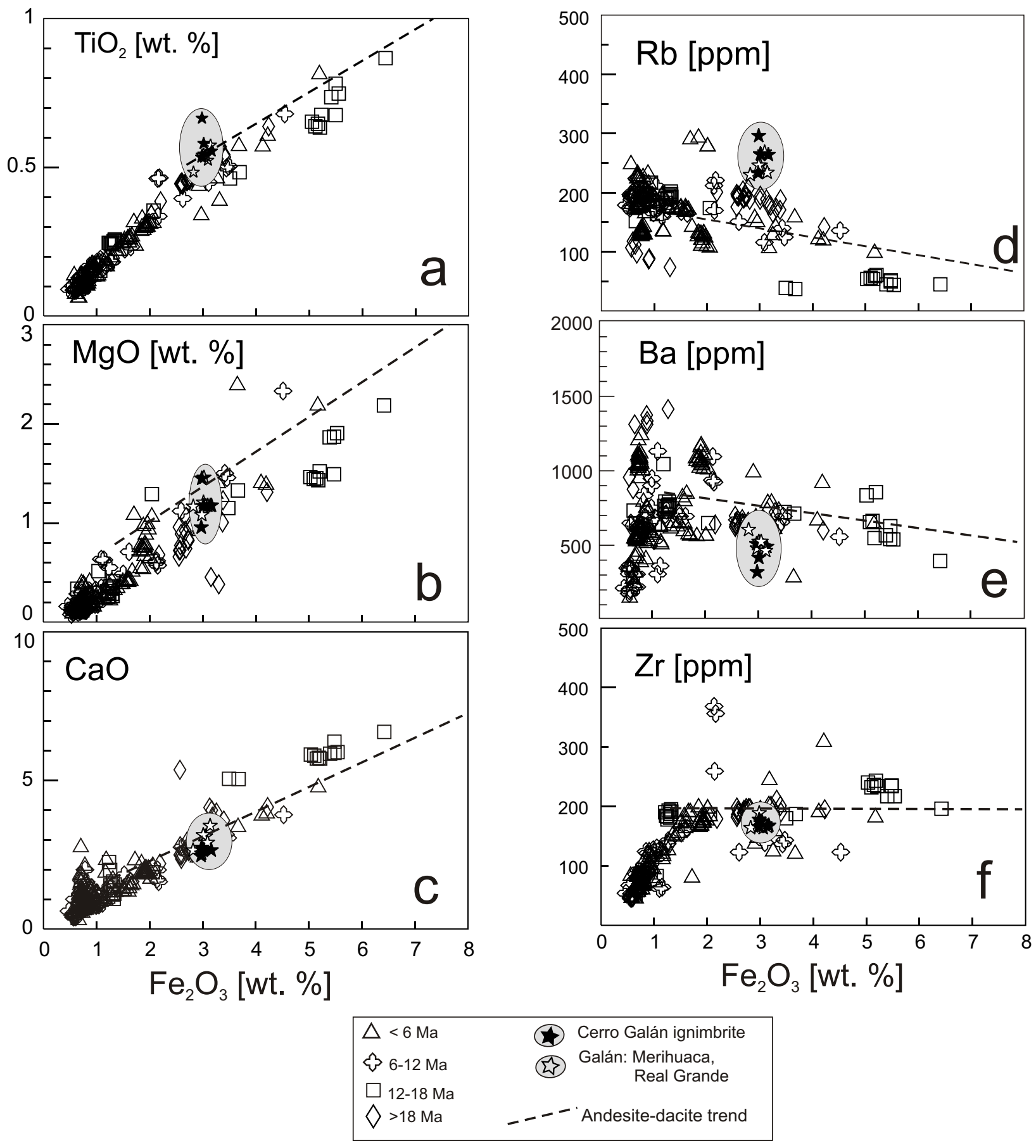

Schnurr et al., Fig. 5 

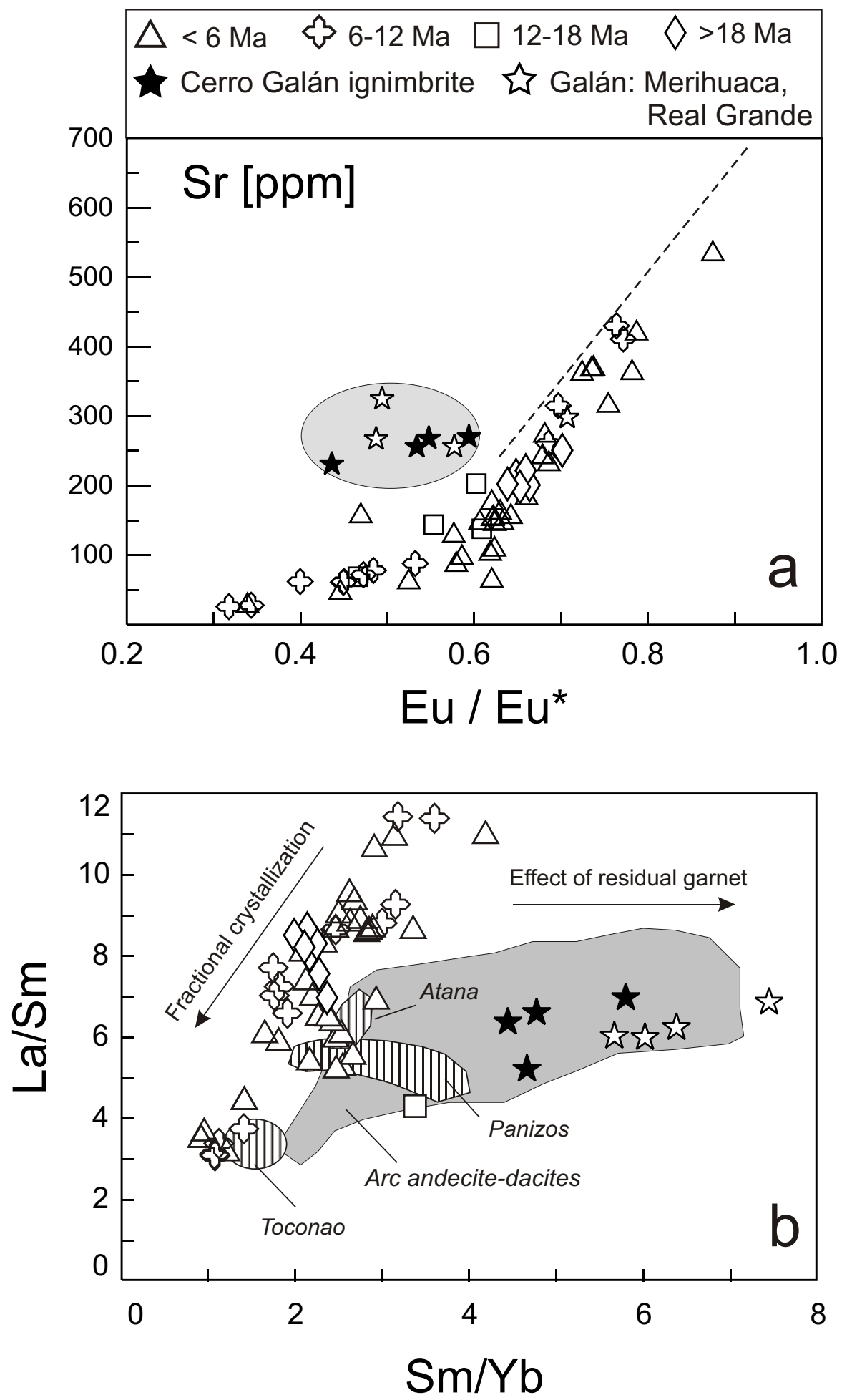

Schnurr et al. Fig. 6 


\section{$\triangle<6 \mathrm{Ma} \& 6-12 \mathrm{Ma} \square 12-18 \mathrm{Ma} \quad \nabla>18 \mathrm{Ma}$}
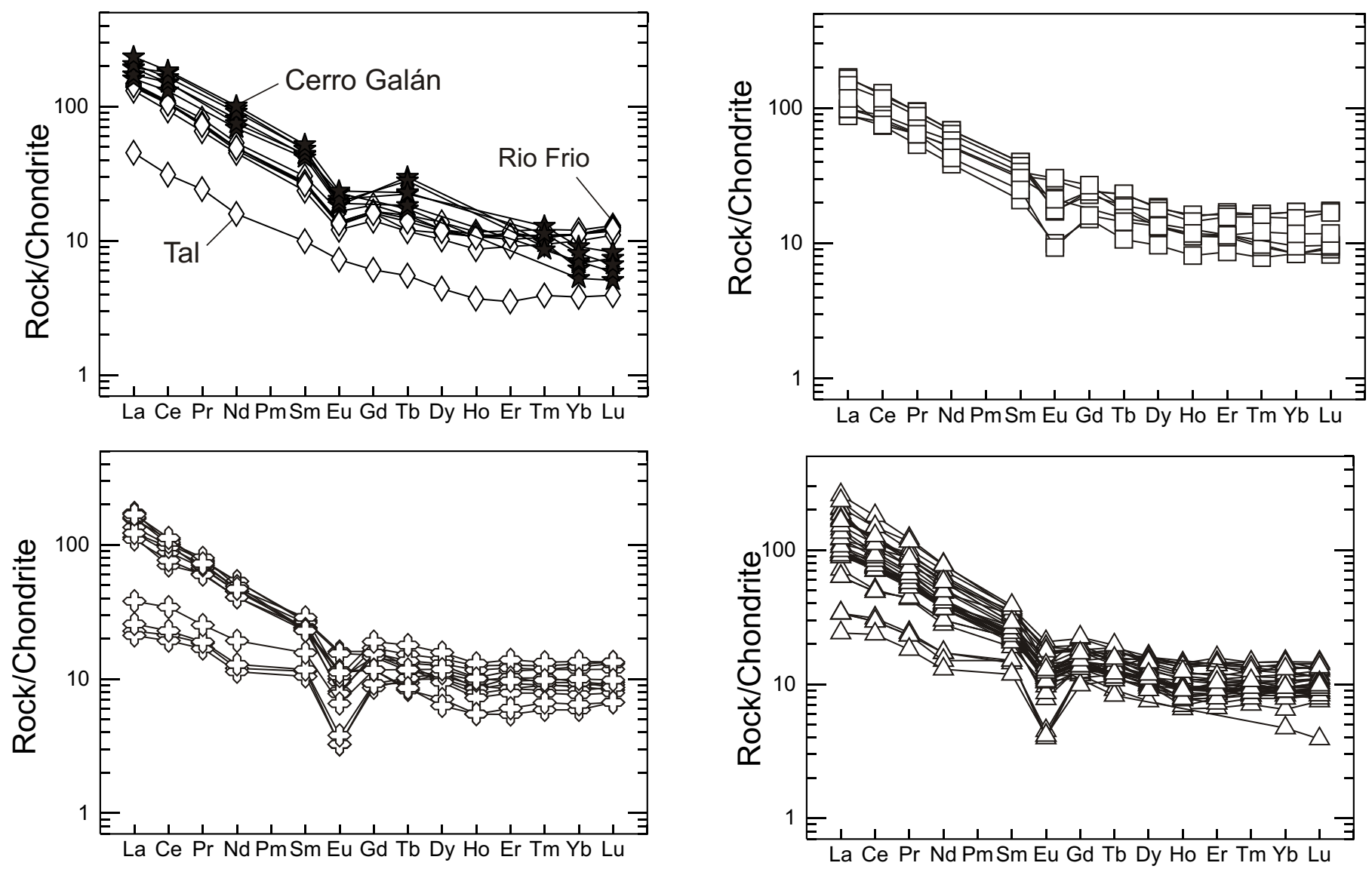

Schnurr et al., Fig. 7 


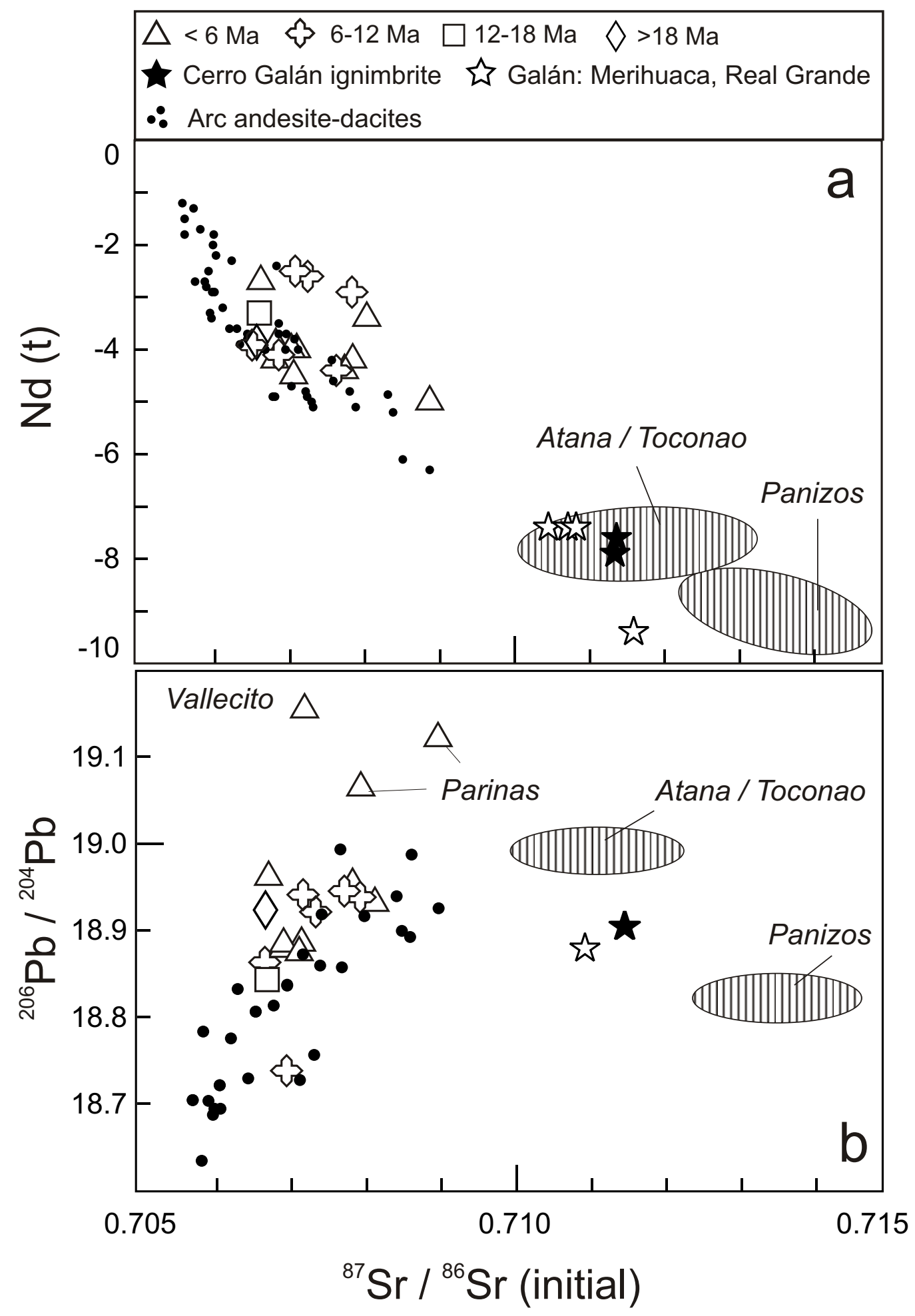

Schnurr et al., Fig. 8 

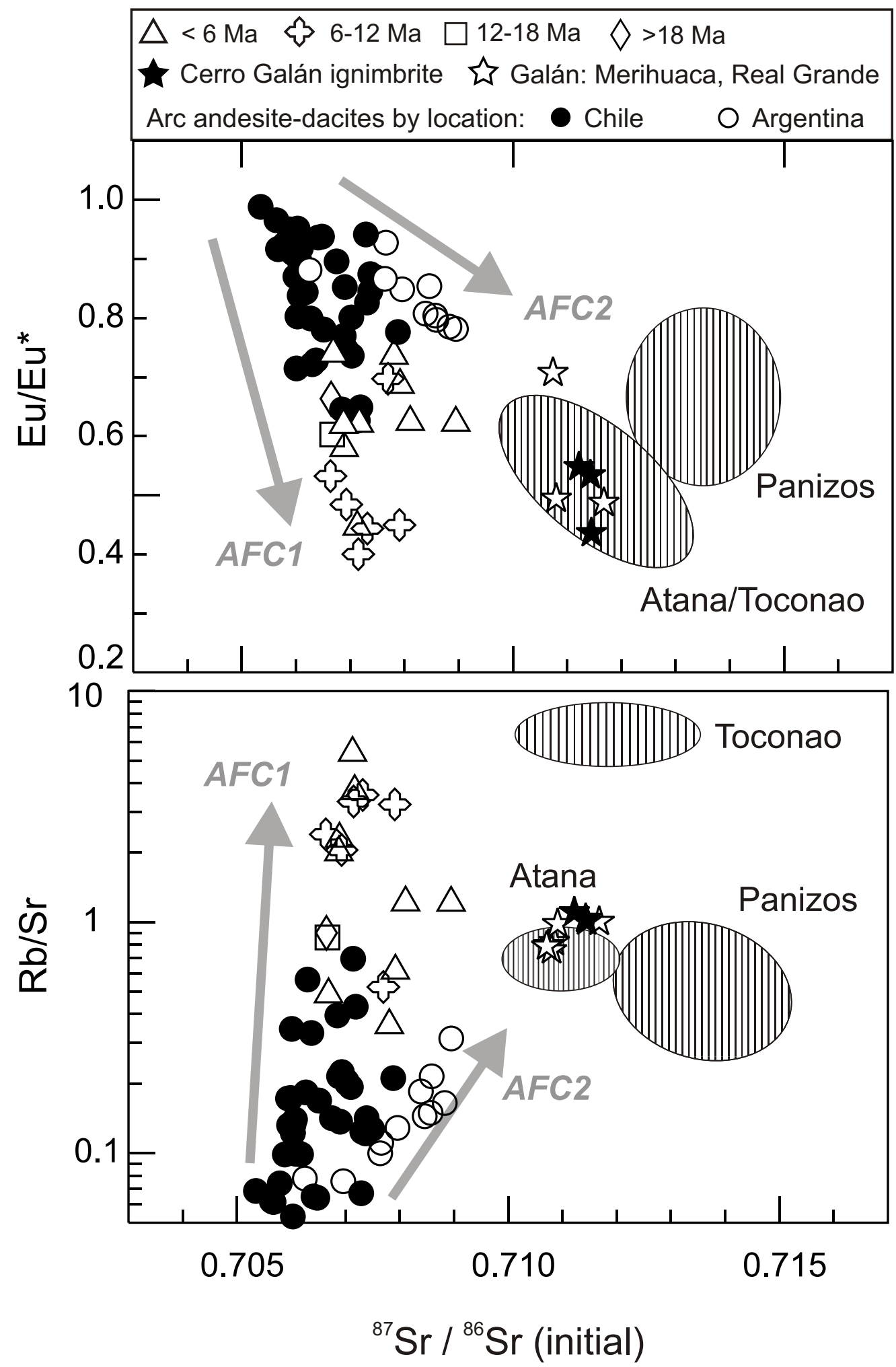

Schnurr et al., Fig. 11 

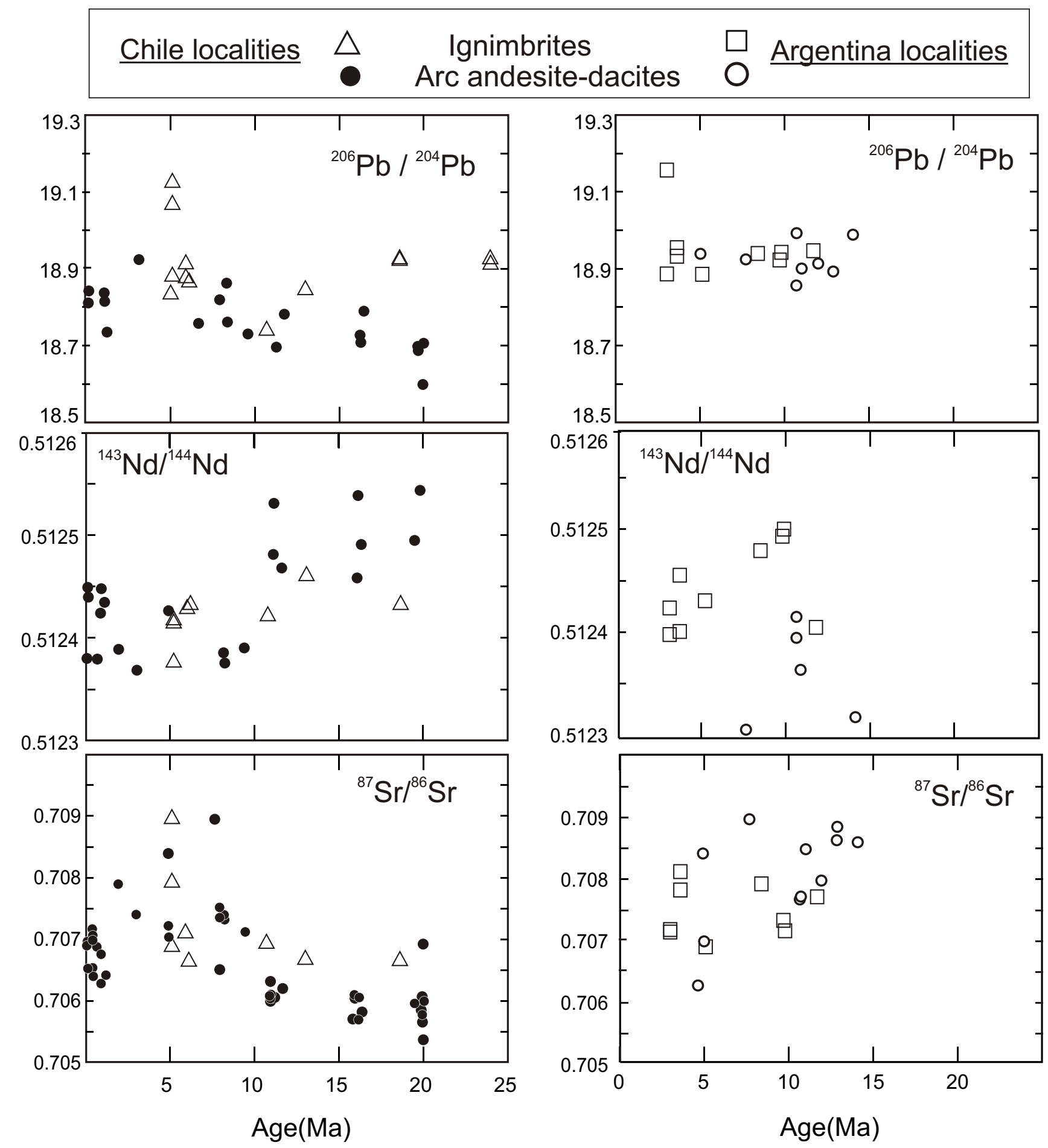

Schnurr et al., Fig. 9 


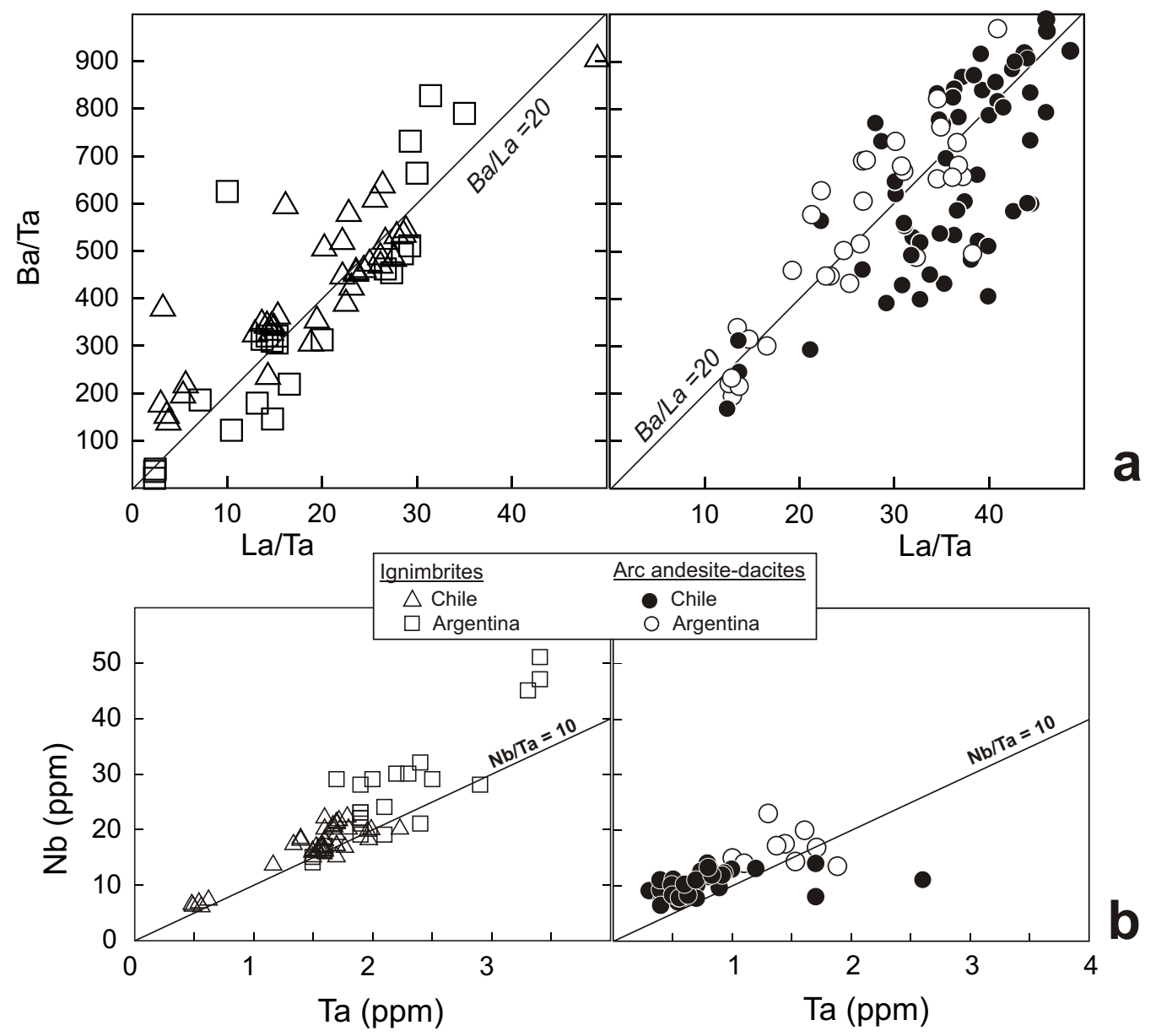

Schnurr et al., Fig. 10 
Table 1. Ignimbrite units in the southern Central Volcanic Zone; units analyzed for this study in bold type.

$$
\text { Chile (west of } \left.68.5^{\circ} \mathrm{W}\right) \quad \text { Argentina (east of } 68.5^{\circ} \mathrm{W} \text { ) }
$$

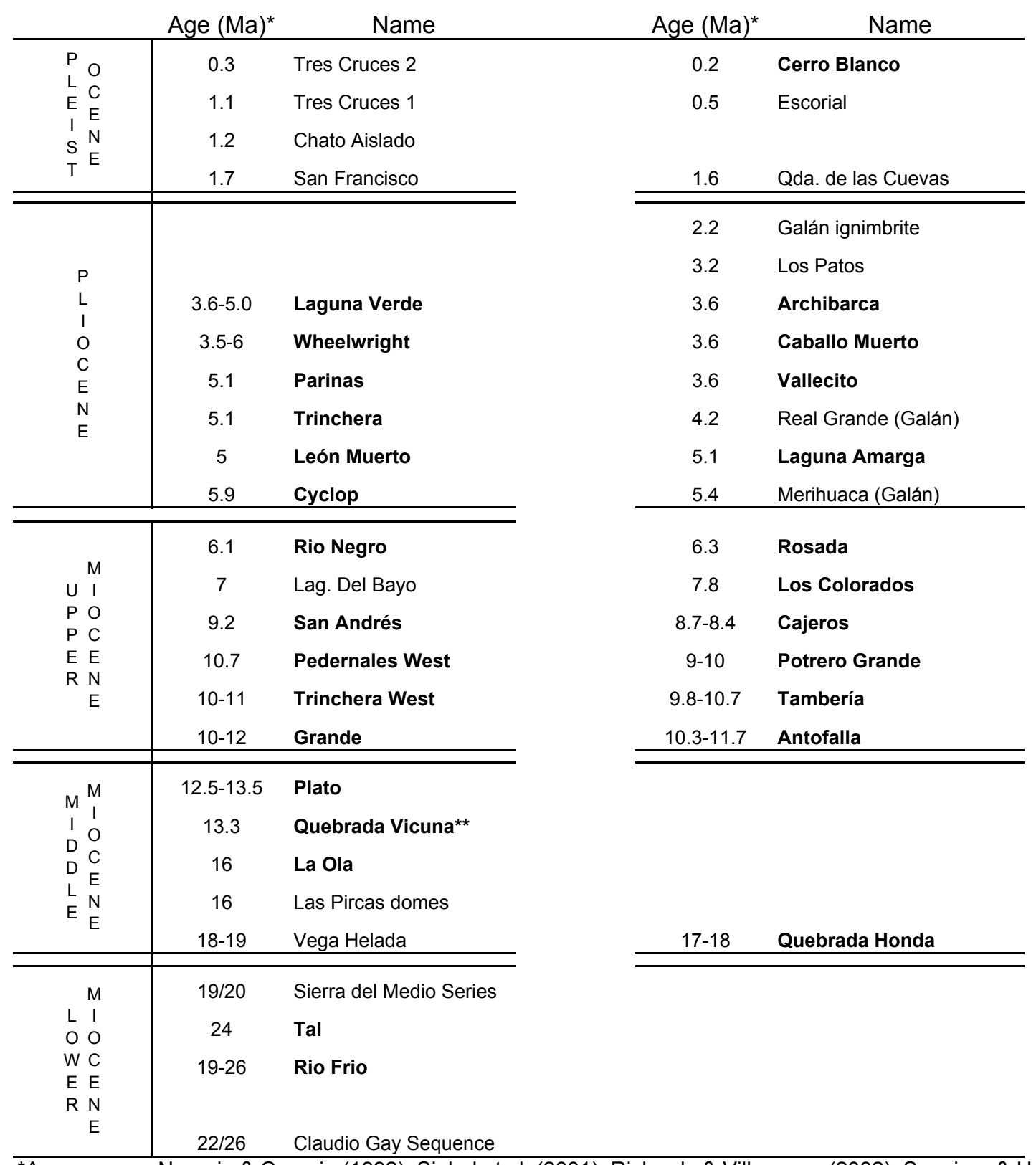

${ }^{*}$ Age sources: Naranjo \& Cornejo (1992), Siebel et al. (2001), Richards \& Villeneuve (2002), Seggiaro \& Hongn (2003) Seggiaro et al. (2006), Clavero et al. (2006a,b); Richards et al. (2006)

** Informal unit outcropping in Salar de Pedernales, Quebrada de Vicuna 
Table 2. Representative whole-rock chemical analyses of ignimbrites from the southern CVZ

\begin{tabular}{|c|c|c|c|c|c|c|c|c|c|c|c|c|c|c|c|c|}
\hline Unit & Cerr & Blanco & Whe & elwright & León Muerto & Cyclop & \begin{tabular}{|l|} 
Archibarca \\
lower
\end{tabular} & & Archibarca upp & & Caba & Io Muerto & & llecito & Lagun & la Verde \\
\hline $\begin{array}{l}\text { Sample } \\
\text { Type } \\
\text { UTM N } \\
\text { UTM E }\end{array}$ & $\begin{array}{r}\text { SIA-97b1 } \\
\text { pumice } \\
62911 \\
7070524\end{array}$ & $\begin{array}{c}\text { SIA-97b3 } \\
\text { pumice } \\
62911 \\
7070524\end{array}$ & $\begin{array}{r}\text { JCO-6-1 } \\
\text { pumice } \\
523125 \\
7040050\end{array}$ & $\begin{array}{c}\text { JCO-6-2 } \\
\text { pumice } \\
525600 \\
7040200\end{array}$ & $\begin{array}{c}\text { T2/13 } \\
\text { matrix } \\
552934 \\
7138791\end{array}$ & $\begin{array}{c}\text { CYKLOP-94 } \\
\text { pumice } \\
544788 \\
7100767\end{array}$ & $\begin{array}{r}\text { SIA-32b1 } \\
\text { pumice } \\
615073 \\
7198122 \\
\end{array}$ & $\begin{array}{r}\text { SIA-30b2 } \\
\text { pumice } \\
615073 \\
7198122\end{array}$ & $\begin{array}{c}\text { SIA-3667 } \\
\text { pumice } \\
615073 \\
7198122 \\
\end{array}$ & $\begin{array}{r}\text { SIA-26b1 } \\
\text { pumice } \\
615073 \\
7198122\end{array}$ & $\begin{array}{c}\text { SIA-20b1 } \\
\text { pumice } \\
615073 \\
7198122\end{array}$ & $\begin{array}{r}\text { SIA-160b1 } \\
\text { pumice } \\
615073 \\
7198122 \\
-30\end{array}$ & $\begin{array}{c}\text { SIA83b8 } \\
\text { pumice } \\
587738 \\
7069871\end{array}$ & $\begin{array}{c}\text { SIA92/ea } \\
\text { pumice } \\
60229 \\
7109195 \\
\end{array}$ & $\begin{array}{l}\text { JCO-4-7a } \\
\text { pumice } \\
556270 \\
7045098\end{array}$ & $\begin{array}{r}\text { JCO-17-1 } \\
\text { pumice } \\
541550 \\
7055000\end{array}$ \\
\hline & & & & & & & $\begin{array}{r}<3.6 \\
\end{array}$ & $<3.6$ & & $<3.6$ & $<3.6$ & $<3.6$ & 3.6 & 3.6 & & \\
\hline & & & & & & 73.5 & & 68.5 & 68.7 & 69.2 & 72.7 & 64.5 & 74.8 & 74.4 & 64.9 & $\begin{array}{ll}73.8 \\
\end{array}$ \\
\hline $\mathrm{TiO}_{2}$ & 0.24 & 0.35 & 0.55 & 0.80 & 0.44 & 0.17 & 0.10 & 0.30 & 0.29 & 0.29 & 0.07 & 0.54 & 0.13 & 0.14 & 0.60 & 0.13 \\
\hline & 13.6 & 13.9 & 15.9 & 15.8 & 15.1 & 13.4 & 13.2 & 15.0 & 14.7 & 15.0 & 13.7 & 14.7 & 12.6 & 12.6 & 16.5 & 12.7 \\
\hline $\mathrm{Fe}_{2} \mathrm{O}_{3}$ (total $\mathrm{F}$ & 1.45 & 2.42 & 3.96 & 5.09 & 3.11 & 0.88 & 0.73 & 1.85 & 1.84 & 1.84 & 0.55 & 3.49 & 0.54 & 0.85 & 4.16 & 0.96 \\
\hline Mno & 0.06 & 0.05 & 0.09 & 0.08 & 0.11 & 0.07 & 0.09 & 0.09 & 0.10 & 0.09 & 0.14 & 0.14 & 0.07 & 0.07 & 0.10 & 0.06 \\
\hline $\begin{array}{l}\mathrm{MgO} \\
\mathrm{CaO}\end{array}$ & 0.37 & 1.06 & 1.35 & 2.15 & 1.24 & 0.15 & 0.18 & 0.84 & 0.72 & 0.64 & 0.10 & 2.28 & 0.08 & 0.39 & 1.37 & 0.22 \\
\hline $\begin{array}{l}\mathrm{ClO}_{\mathrm{Na}} \mathrm{O} \\
\mathrm{Na}_{2}\end{array}$ & $\begin{array}{l}1.32 \\
3.37 \\
\end{array}$ & $\begin{array}{r}5.15 \\
3.57\end{array}$ & 3.69 & $\begin{array}{l}4.70 \\
408\end{array}$ & 2.294 & 0.79 & 0.08 & 1.86 & 1.97 & 1.81 & 0.51 & 3.28 & 0.55 & 0.68 & 3.86 & 1.19 \\
\hline $\begin{array}{l}\mathrm{K}_{2} \mathrm{O} \\
\mathrm{a}\end{array}$ & 484 & 3.57 & 3.07 & $\begin{array}{l}4.08 \\
2.07\end{array}$ & $\begin{array}{l}2.99 \\
3.66\end{array}$ & 5.507 & 3.88 & 3.05 & 4.12 & 4.19 & $\begin{array}{l}3.51 \\
4.89\end{array}$ & $\begin{array}{l}3.20 \\
3.38\end{array}$ & $\begin{array}{ll}2.12 \\
5.97\end{array}$ & $\begin{array}{l}5.10 \\
2.92\end{array}$ & $\begin{array}{l}4.48 \\
3.39\end{array}$ & $\begin{array}{l}3.40 \\
552\end{array}$ \\
\hline $\mathrm{P}_{2} \mathrm{O}_{5}$ & 0.08 & $\begin{array}{l}.3 .12 \\
0.12\end{array}$ & 0.15 & $\begin{array}{l}.297 \\
0.22\end{array}$ & $\begin{array}{l}.0 .60 \\
0.13\end{array}$ & $\begin{array}{l}5.03 \\
0.03\end{array}$ & $\begin{array}{l}4.88 \\
0.05\end{array}$ & $\begin{array}{l}4.27 \\
0.11\end{array}$ & $\begin{array}{l}3.51 \\
0.12\end{array}$ & $\begin{array}{l}4.34 \\
0.12\end{array}$ & $\begin{array}{l}4.89 \\
0.06\end{array}$ & $\begin{array}{l}.3 .88 \\
0.16\end{array}$ & $\begin{array}{l}.8 .03 \\
0.03\end{array}$ & $\begin{array}{l}2.92 \\
0.02\end{array}$ & $\begin{array}{l}3.29 \\
0.25\end{array}$ & $\begin{array}{l}5.23 \\
0.07\end{array}$ \\
\hline $\mathrm{H}_{2} \mathrm{O}$ & 2.03 & 1.79 & 3.18 & 0.96 & 3.55 & 2.17 & 3.88 & 3.52 & 3.07 & 3.10 & 3.63 & 3.85 & 1.84 & 2.19 & 0.23 & 1.82 \\
\hline $\mathrm{CO}_{2}$ & 0.11 & 2.23 & 0.01 & 0.01 & 0.15 & 0.10 & 0.06 & 0.07 & 0.06 & 0.05 & 0.06 & 0.12 & 0.06 & 0.07 & & \\
\hline Total & 99.3 & 99.5 & 100.1 & 99.9 & 100.0 & 99.9 & 99.5 & 99.4 & 99.2 & 99.7 & 100.0 & 99.8 & 99.3 & 99.4 & 99.8 & 99.6 \\
\hline$v$ & 16 & 45 & 53 & 92 & $<10$ & $<10$ & $<10$ & 18 & 21 & 21 & $<10$ & 68 & $<10$ & 11 & $<10$ & $<10$ \\
\hline $\mathrm{Cr}$ & $<10$ & 19 & $<10$ & 20 & $<10$ & $<10$ & $<10$ & $<10$ & $<10$ & $<10$ & $<10$ & 67 & $<10$ & $<10$ & $<10$ & $<10$ \\
\hline $\mathrm{Ni}$ & $<10$ & 10 & $<10$ & 10 & $<10$ & $<10$ & $<10$ & $<10$ & $<10$ & $<10$ & $<10$ & 25 & $<10$ & $<10$ & $<10$ & $<10$ \\
\hline $\mathrm{Zn}$ & 37 & $\begin{array}{l}41 \\
146\end{array}$ & 121 & 98 & $\begin{array}{r}69 \\
188\end{array}$ & $\begin{array}{l}36 \\
181\end{array}$ & $\begin{array}{l}40 \\
13\end{array}$ & $\begin{array}{c}54 \\
131\end{array}$ & $\begin{array}{r}53 \\
126\end{array}$ & 50 & 38 & $\begin{array}{r}69 \\
69\end{array}$ & 35 & 32 & 84 & 27 \\
\hline $\mathrm{Sr}$ & 241 & $\begin{array}{l}4160 \\
301\end{array}$ & 419 & 477 & 315 & 128 & 108 & 367 & $\begin{array}{l}120 \\
362\end{array}$ & $\begin{array}{l}114 \\
361\end{array}$ & 27 & $\begin{array}{l}158 \\
182\end{array}$ & $\begin{array}{c}248 \\
46\end{array}$ & $\begin{array}{l}232 \\
63\end{array}$ & $\begin{array}{l}1199 \\
533\end{array}$ & $\begin{array}{l}994 \\
103\end{array}$ \\
\hline & & & 17 & & & & & & & & & & & 13 & & \\
\hline $\mathrm{zr}$ & $\begin{array}{l}10 \\
171\end{array}$ & $\begin{array}{l}\circ \\
122\end{array}$ & 190 & $\begin{array}{l}10 \\
181\end{array}$ & $\begin{array}{l}1124 \\
\end{array}$ & $\begin{array}{l}10 \\
124\end{array}$ & $\begin{array}{l}74 \\
70\end{array}$ & $\begin{array}{l}10 \\
177\end{array}$ & $\begin{array}{l}172 \\
172\end{array}$ & $\begin{array}{l}10 \\
173\end{array}$ & 46 & 120 & $\begin{array}{l}144 \\
83\end{array}$ & $\begin{array}{l}10 \\
93\end{array}$ & $\begin{array}{l}10 \\
308\end{array}$ & $\begin{array}{l}10 \\
94\end{array}$ \\
\hline & 30 & 29 & 13 & 10 & 17 & 18 & 29 & 25 & 23 & 23 & 45 & 31 & 19 & 19 & 13 & 17 \\
\hline Ba & 639 & 335 & 652 & 627 & 772 & 735 & 1063 & 1024 & 1158 & 1106 & 132 & 268 & 340 & 390 & 904 & 566 \\
\hline La & & $\begin{array}{l}34 \\
5\end{array}$ & 35 & & 21 & $\begin{array}{l}39 \\
70\end{array}$ & 17 & 41 & 44 & 49 & 8 & 23 & 25 & 15 & 49 & 29 \\
\hline $\begin{array}{c}\mathrm{Ce} \\
\mathrm{PPr}\end{array}$ & & $\begin{array}{l}59 \\
665\end{array}$ & $\begin{array}{l}67 \\
74\end{array}$ & & $\begin{array}{l}46 \\
553\end{array}$ & $\begin{array}{l}78 \\
82\end{array}$ & $\begin{array}{l}31 \\
44\end{array}$ & 75 & 70 & 91 & 18 & 43 & 48 & 30.0 & 88 & 44 \\
\hline d & & . & 1.4 & & 19 & 8.2 & $\begin{array}{l}4.1 \\
.12\end{array}$ & 8.2 & 9.0 & 9.6 & 2.2 & 5.3 & 5.8 & 4.2 & 9.7 & 5.9 \\
\hline $\mathrm{Sm}$ & & $\begin{array}{l}20 \\
3.2\end{array}$ & $\begin{array}{l}28 \\
5.0\end{array}$ & & $\begin{array}{r}19 \\
3.9\end{array}$ & $\begin{array}{l}27 \\
4.4\end{array}$ & 2.9 & $\begin{array}{l}28 \\
4.8\end{array}$ & $\begin{array}{l}29 \\
5.0\end{array}$ & $\begin{array}{l}33 \\
5.7\end{array}$ & $\begin{array}{c}8 \\
2.2\end{array}$ & $\begin{array}{r}18 \\
3.8\end{array}$ & $\begin{array}{l}18 \\
3.4\end{array}$ & $\begin{array}{l}14 \\
3.4\end{array}$ & $\begin{array}{l}35 \\
5.7\end{array}$ & $\begin{array}{l}19 \\
3.1\end{array}$ \\
\hline Eu & & 0.67 & 1.15 & & 0.95 & 0.74 & 0.56 & 1.00 & 1.10 & 1.20 & 0.26 & 0.81 & 0.45 & 0.70 & 1.39 & 0.52 \\
\hline Gd & & $\begin{array}{l}2.4 \\
\end{array}$ & $\begin{array}{l}4.0 \\
\end{array}$ & & $\begin{array}{l}3.8 \\
0.5\end{array}$ & $\begin{array}{l}3.5 \\
0\end{array}$ & $\begin{array}{l}2.6 \\
\text {. }\end{array}$ & $\begin{array}{l}3.6 \\
\end{array}$ & $\begin{array}{l}3.7 \\
\end{array}$ & $\begin{array}{l}4.5 \\
\end{array}$ & $\begin{array}{r}2.5 \\
\end{array}$ & $\begin{array}{l}3.7 \\
0.7\end{array}$ & 2.8 & 3.5 & $\begin{array}{l}4.2 \\
\text {. }\end{array}$ & $\begin{array}{l}2.4 \\
\end{array}$ \\
\hline $\begin{array}{l}\text { Tb } \\
\text { Dy }\end{array}$ & & 0.34 & 0.59 & & 0.55 & 0.58 & $\begin{array}{l}0.45 \\
27\end{array}$ & 0.52 & 0.57 & 0.68 & 0.56 & 0.70 & 26 & $\begin{array}{l}0.670 \\
33\end{array}$ & 0.61 & 0.27 \\
\hline $\begin{array}{l}\text { Dy } \\
\text { Ho }\end{array}$ & & $\begin{array}{l}1.9 \\
0.37\end{array}$ & $\begin{array}{l}3.1 \\
0.61\end{array}$ & & $\begin{array}{l}3.2 \\
0.63\end{array}$ & $\begin{array}{l}3.0 \\
0.51\end{array}$ & $\begin{array}{l}2.1 \\
0.52\end{array}$ & $\begin{array}{l}2.8 \\
0.54\end{array}$ & $\begin{array}{l}3.3 \\
0.61\end{array}$ & $\begin{array}{l}3.6 \\
0.67\end{array}$ & $\begin{array}{l}4.0 \\
0.80\end{array}$ & $\begin{array}{l}4.1 \\
0.79\end{array}$ & $\begin{array}{l}2.6 \\
0.45\end{array}$ & $\begin{array}{l}3.8 \\
0.76\end{array}$ & $\begin{array}{l}3.2 \\
0.63\end{array}$ & $\begin{array}{l}2.1 \\
0.40\end{array}$ \\
\hline $\mathrm{Er}$ & & 1.1 & 1.8 & & 1.7 & 17 & 16 & 16 & $\begin{array}{l}1.8 \\
18\end{array}$ & 20 & 24 & 24 & 14 & 2.30 & 17 & 1.42 \\
\hline $\mathrm{Tm}$ & & 0.18 & 0.25 & & 0.26 & 0.27 & 0.25 & 0.26 & $\begin{array}{l}0.09 \\
0.29\end{array}$ & 0.29 & 0.35 & $\begin{array}{l}2.45 \\
0.35\end{array}$ & $\begin{array}{l}0.44 \\
0.24\end{array}$ & 0.3 & 0.27 & 0.18 \\
\hline Yb & & 1.1 & 1.7 & & 1.8 & 1.6 & 1.6 & 1.7 & 1.9 & 2.0 & 2.3 & 2.3 & 1.6 & 2.4 & 1.7 & 1.3 \\
\hline Lu & & 0.19 & 0.27 & & 0.27 & 0.25 & 0.25 & 0.28 & 0.30 & 0.32 & 0.33 & 0.33 & 0.26 & 0.36 & 0.27 & 0.16 \\
\hline Li & 39 & 39 & 33 & & 38 & 38 & 13 & 36 & 31 & 22 & 13 & 19 & 41 & 49 & 47 & 42 \\
\hline Sc & 2.6 & 4.6 & 6.7 & & & 1.9 & 2.2 & 2.7 & 4.0 & 4.4 & 4.2 & 9.9 & 2.1 & & 5.4 & 2.4 \\
\hline $\begin{array}{l}\text { Cu } \\
\text { Ga }\end{array}$ & $\begin{array}{l}4.7 \\
18\end{array}$ & $\begin{array}{l}4.6 \\
16\end{array}$ & $\begin{array}{l}9.5 \\
21\end{array}$ & & $\begin{array}{l}9.0 \\
18\end{array}$ & $\begin{array}{l}4.0 \\
15\end{array}$ & $\begin{array}{l}1.2 \\
17\end{array}$ & $\begin{array}{l}3.6 \\
18\end{array}$ & $\begin{array}{l}3.1 \\
19\end{array}$ & $\begin{array}{l}3.5 \\
19\end{array}$ & $\begin{array}{l}0.8 \\
20\end{array}$ & $\begin{array}{l}9.0 \\
19\end{array}$ & $\begin{array}{l}8.7 \\
14\end{array}$ & $\begin{array}{l}2.1 \\
15\end{array}$ & $\begin{array}{c}10.7 \\
21\end{array}$ & $\begin{array}{c}10.9 \\
15\end{array}$ \\
\hline Mo & 2.6 & 2.4 & 2.3 & & $\begin{array}{l}1.8 \\
1.8\end{array}$ & 2.1 & 1.7 & $\begin{array}{l}10 \\
1.9\end{array}$ & 2.0 & $\begin{array}{l}1.7 \\
\end{array}$ & $\begin{array}{l}20 \\
1.8\end{array}$ & 4.0 & $\begin{array}{l}14 \\
4.7\end{array}$ & & $\begin{array}{l}2.1 \\
2.7\end{array}$ & $\begin{array}{l}15 \\
4.6\end{array}$ \\
\hline Sn & 1.7 & 1.6 & 2.0 & & 1.8 & 1.3 & 1.6 & 2.8 & 2.4 & 1.7 & 2.3 & 2.6 & 0.5 & 1.9 & 1.8 & 2.1 \\
\hline Cs & 7.3 & 7.2 & 5.1 & & 6.6 & 7.2 & 3.4 & 3.2 & 3.2 & 2.9 & 5.7 & 6.4 & 13.7 & 12 & 4.3 & 12.7 \\
\hline Ta & 2.3 & $\begin{array}{l}2.3 \\
\end{array}$ & $\begin{array}{l}1.2 \\
1.2\end{array}$ & & 1.3 & 1.6 & 1.7 & 1.4 & 1.4 & 1.4 & 3.3 & 2.2 & 1.9 & 2.1 & 1.0 & 1.7 \\
\hline $\begin{array}{l}\text { Pb } \\
\text { Th }\end{array}$ & $\begin{array}{l}20.7 \\
25\end{array}$ & $\begin{array}{l}19.2 \\
27\end{array}$ & $\begin{array}{c}17.0 \\
14\end{array}$ & & $\begin{array}{l}16.0 \\
10\end{array}$ & $\begin{array}{c}22.0 \\
17\end{array}$ & $\begin{array}{r}22.6 \\
9\end{array}$ & $\begin{array}{l}20.9 \\
13\end{array}$ & $\begin{array}{l}25.0 \\
12\end{array}$ & 21.0 & 21.0 & 15.0 & 8.0 & $\begin{array}{r}29 \\
20\end{array}$ & 16.4 & 21.2 \\
\hline u & $\begin{array}{l}20 \\
7.2\end{array}$ & $\begin{array}{l}21 \\
6.8\end{array}$ & $\begin{array}{l}14 \\
4.5\end{array}$ & & 2.8 & 5.7 & 3.9 & $\begin{array}{l}13 \\
3.2\end{array}$ & $\begin{array}{l}12 \\
3.3\end{array}$ & $\begin{array}{l}12 \\
3.4\end{array}$ & $\begin{array}{l}8 \\
6.8\end{array}$ & $\begin{array}{l}7 \\
4.1\end{array}$ & $\begin{array}{l}28 \\
10.7\end{array}$ & $\begin{array}{l}30 \\
11\end{array}$ & $\begin{array}{l}20 \\
4.5\end{array}$ & $\begin{array}{l}28 \\
9.5\end{array}$ \\
\hline${ }^{206} \mathrm{~Pb} /{ }^{204} \mathrm{~Pb}$ & & 18.962 & 18.792 & & 18.833 & 18.875 & 18.932 & 18.954 & & & & & 18.886 & 19.155 & & 18.827 \\
\hline${ }^{207} \mathrm{~Pb} /{ }^{204} \mathrm{~Pb}$ & & 15.643 & 15.620 & & 15.623 & 15.634 & 15.641 & 15.636 & & & & & 15.621 & 15.698 & & 15.613 \\
\hline${ }^{208} \mathrm{~Pb}$ & & 39.001 & 38.779 & & 38.794 & 38.922 & 38.864 & 38.855 & & & & & 38.876 & 39.202 & & 38.803 \\
\hline & & 0.70669 & 0.70672 & & & 0.70710 & 0.70811 & 0.70781 & & & & & 0.70713 & 0.70717 & & 0.70691 \\
\hline${ }_{\varepsilon}^{134} \mathrm{Ndd} /(4) \mathrm{Nd}$ & & $\begin{array}{l}0.512492 \\
-2.8\end{array}$ & $\begin{array}{l}0.512416 \\
-4.2\end{array}$ & & & $\begin{array}{l}0.512428 \\
-4.0\end{array}$ & $\begin{array}{c}0.512459 \\
-3.4\end{array}$ & $\begin{array}{l}0.512404 \\
-4.5\end{array}$ & & & & & $\begin{array}{l}0.512401 \\
-4.5\end{array}$ & $\begin{array}{l}0.512427 \\
-4.1\end{array}$ & & $\begin{array}{c}0.512404 \\
-4.5\end{array}$ \\
\hline
\end{tabular}

New isotope data from Table 4 are listed in bold type, previously published data are from $\operatorname{sinbel}$ et al. (2001) and Schnurr (2001). 


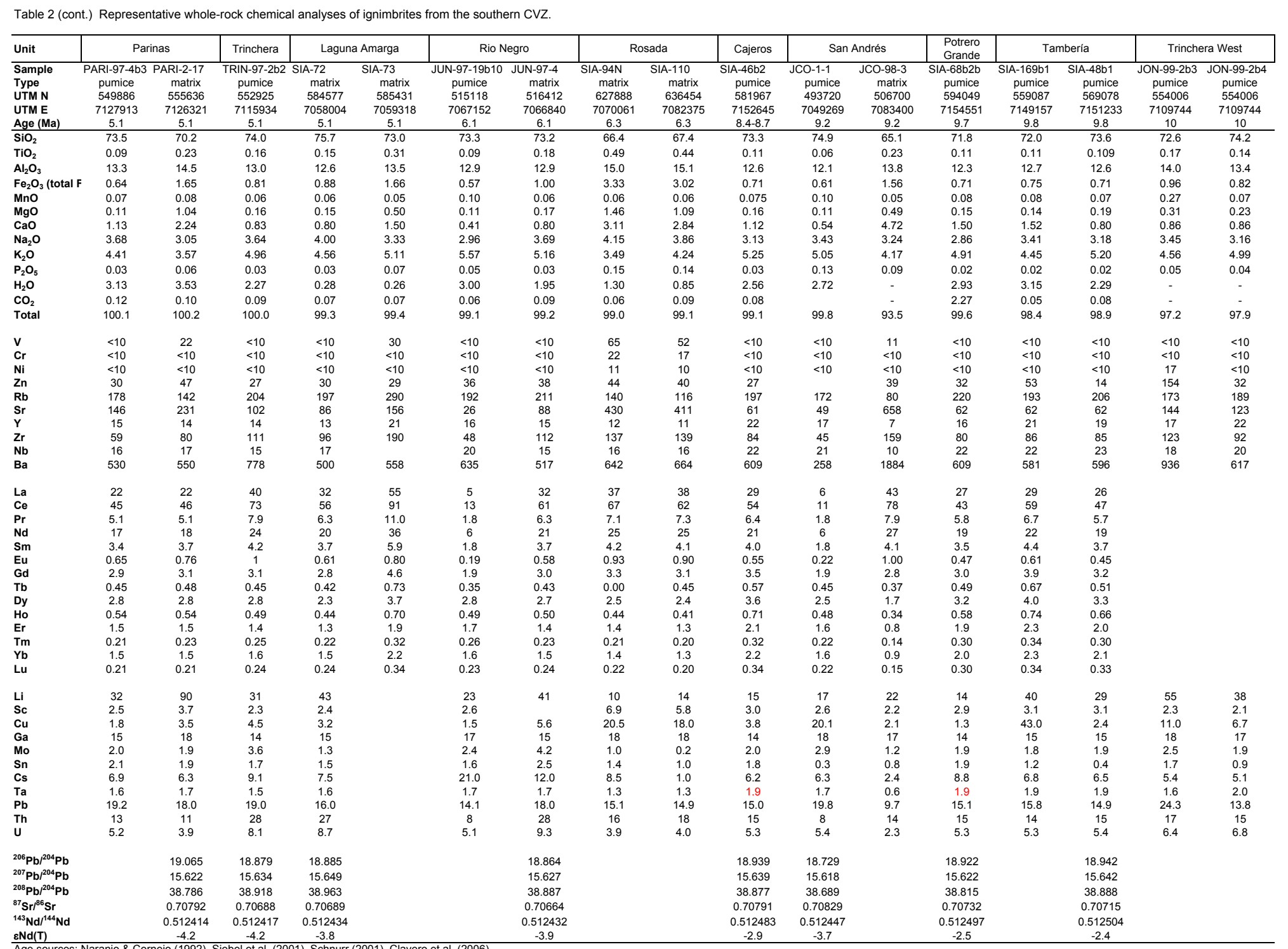

Age sources: Naranjo \& Cornejo (1992), Siebel et al. (2001), Schnurr (2001), Clavero et al. (2006).
New isotope data from Table 4 are listed in bold type, previously published data are from Siebel et al. (2001) and Schnur (2001).
All isotope ratios are initial values calculated from the ages given and using measured U, Th, Pb, Sr, Rb, Sm and Nd concentrations. 


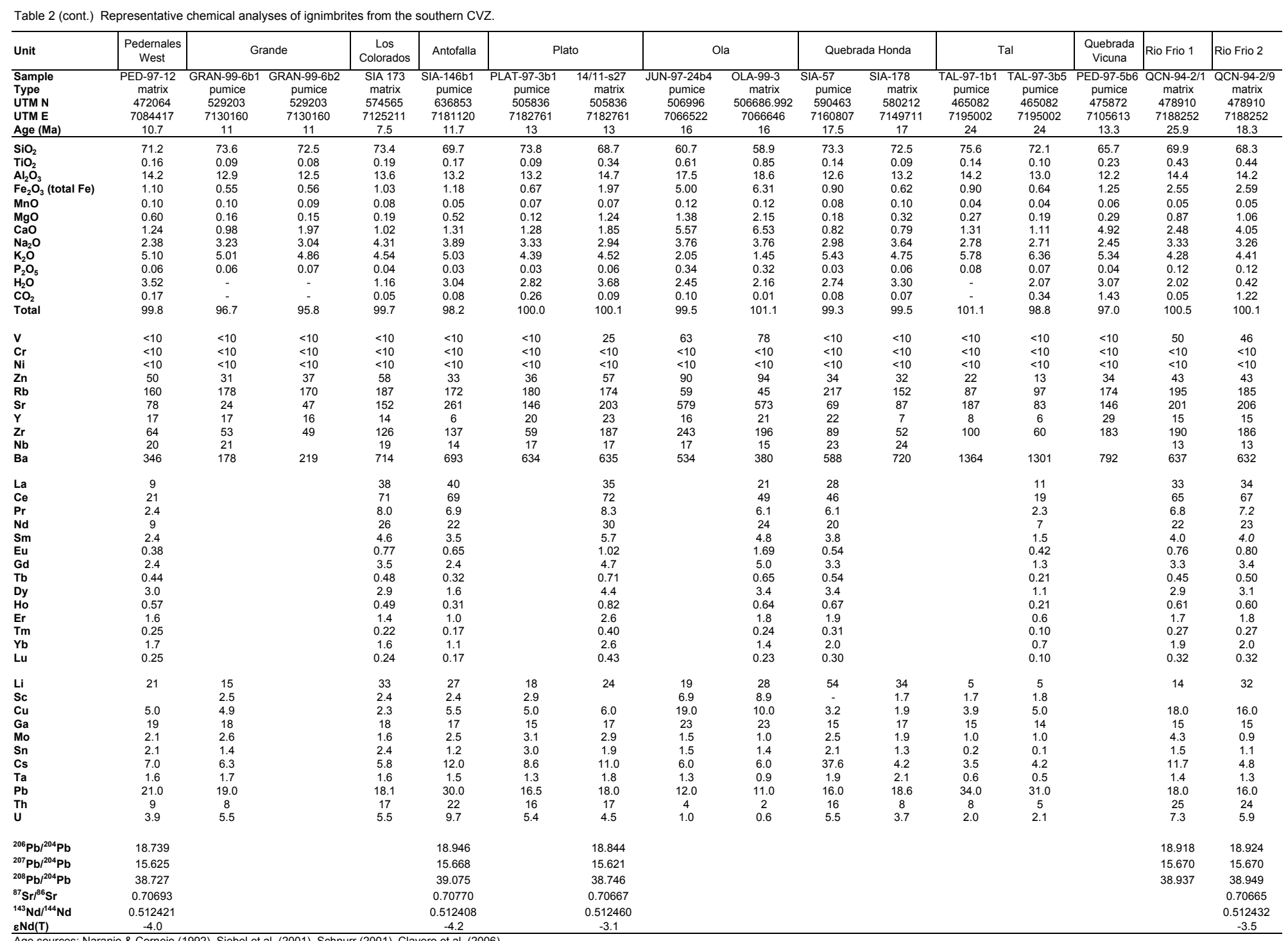

Age sources: Naranjo \& Cornejo (1992), Siebel et al. (2001), Schnurr (2001), Clavero et al. (2006).

New isotope data from Table 4 are listed in bold type, previously published data are from Siebel et al. (2001) and Schnurr (2001). 


\begin{tabular}{|c|c|c|c|c|c|c|c|c|c|c|c|c|c|c|}
\hline \multirow{2}{*}{$\frac{\text { Unit }}{\text { Sample }}$} & \multicolumn{2}{|c|}{ Sierra Nevada } & \multicolumn{2}{|c|}{ Azufrera Cuyanos } & \multicolumn{2}{|c|}{ Volcán Laguna } & \multicolumn{2}{|c|}{ Cerros Colorados } & \multirow{2}{*}{ 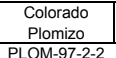 } & \multicolumn{2}{|c|}{ Volcán Piedra Paradra } & \multicolumn{2}{|c|}{ Tridente } & \multirow{2}{*}{$\begin{array}{c}\text { Puntiagudo de la } \\
\text { Isla } \\
\text { GRAN-99-18 }\end{array}$} \\
\hline & NEVA-97-5 & NEVA-97-4 & CUY-97-1 & CUY-97-3 & LAG-97-1 & LAG-97-2 & CUM-99-1 & CUM-99-5 & & PARAD-97-1 & $\begin{array}{l}\text { PARAD-94-2 } \\
\end{array}$ & TRIDE-94-1 & TRIDE-94-3 & \\
\hline UTM N & 539620 & 539620 & 533906 & 533906 & 530650 & 530650 & 556105 & 553419 & 535591 & 526214 & 526214 & 544064 & 544064 & 541143 \\
\hline UTME & 7081033 & 7081033 & 7078311 & 7078311 & 7060722 & 7060722 & 7107583 & 7110677 & 7076830 & 7082851 & 7082851 & 7098123 & 7098123 & 7127906 \\
\hline Age (Ma) & 1 & 1 & 1 & 1 & 1.2 & 1.2 & 3.1 & 3.1 & 5.7 & 9.5 & 9.5 & 11.7 & 11.7 & 16.4 \\
\hline $\mathrm{SiO}_{2}$ & 58.1 & 58.5 & 58.6 & 61.5 & 54.8 & 54.6 & 58.1 & 54.3 & 60.2 & 58.6 & 60.5 & 55.4 & 61.7 & 56.3 \\
\hline $\mathrm{TiO}_{2}$ & 0.98 & 1.11 & 0.90 & 0.73 & 1.18 & 1.195 & 0.96 & 1.22 & 0.80 & 0.96 & 0.95 & 1.22 & 0.85 & 1.43 \\
\hline $\mathrm{Al}_{2} \mathrm{O}_{3}$ & 17.7 & 18.4 & 16.6 & 16.2 & 17.5 & 17.22 & 17.3 & 17.1 & 16.0 & 17.8 & 17.2 & 18.1 & 18.0 & 17.0 \\
\hline $\mathrm{Fe}_{2} \mathrm{O}_{3}$ (total $\mathrm{Fe}$ ) & 6.65 & 7.16 & 6.39 & 5.06 & 8.39 & 8.45 & 6.85 & 8.51 & 5.51 & 6.41 & 5.75 & 7.75 & 4.79 & 7.75 \\
\hline $\mathrm{MnO}$ & 0.10 & 0.10 & 0.10 & 0.08 & 0.12 & 0.12 & 0.11 & 0.13 & 0.09 & 0.11 & 0.09 & 0.10 & 0.07 & 0.14 \\
\hline $\mathrm{MgO}$ & 3.65 & 2.84 & 3.47 & 2.64 & 5.19 & 5.17 & 3.02 & 4.65 & 3.31 & 2.27 & 2.16 & 4.10 & 1.71 & 2.68 \\
\hline $\mathrm{CaO}$ & 6.63 & 6.48 & 6.38 & 5.12 & 7.83 & 7.85 & 6.36 & 7.70 & 5.63 & 5.56 & 5.18 & 7.10 & 5.19 & 5.63 \\
\hline $\mathrm{Na}_{2} \mathrm{O}$ & 3.77 & 4.01 & 3.32 & 3.47 & 3.40 & 3.17 & 3.23 & 3.01 & 3.30 & 3.51 & 3.89 & 3.68 & 3.94 & 4.18 \\
\hline $\mathrm{K}_{2} \mathrm{O}$ & 2.16 & 2.08 & 2.47 & 2.97 & 1.58 & 1.58 & 2.18 & 1.80 & 2.85 & 2.66 & 2.63 & 2.22 & 3.11 & 2.41 \\
\hline $\mathrm{P}_{2} \mathrm{O}_{5}$ & 0.24 & 0.25 & 0.23 & 0.21 & 0.25 & 0.26 & 0.25 & 0.28 & 0.20 & 0.25 & 0.30 & 0.33 & 0.29 & 0.48 \\
\hline $\mathrm{H}_{2} \mathrm{O}$ & 1.12 & 0.55 & 1.02 & 1.35 & 1.30 & 1.25 & 0.71 & 1.14 & 0.99 & 1.25 & 1.58 & 0.80 & 1.11 & 0.37 \\
\hline $\mathrm{CO}_{2}$ & 0.12 & 0.05 & 0.11 & 0.07 & 0.11 & 0.12 & 0.04 & 0.11 & 0.11 & 0.07 & 0.07 & 0.11 & 0.08 & 0.05 \\
\hline Total & 101.2 & 101.5 & 99.5 & 99.4 & 101.6 & 101.0 & 99.1 & 100.0 & 99.0 & 99.4 & 100.3 & 100.8 & 100.7 & 98.4 \\
\hline V & 145 & 152 & 145 & 106 & 191 & 194 & 125 & 186 & 121 & 119 & 17 & 198 & 80 & 117 \\
\hline $\mathrm{Cr}$ & $\begin{array}{l}<10 \\
<10\end{array}$ & & $<10$ & $<10$ & $<10$ & 100 & $<10$ & 65 & $<10$ & $<10$ & $<10$ & 63 & 10 & $<10$ \\
\hline $\mathrm{Ni}$ & 31 & 33 & 23 & 19 & 52 & 49 & 7 & 36 & 34 & 5 & 8 & 41 & 7 & 3 \\
\hline $\mathrm{Zn}$ & 99 & 88 & 100 & 77 & 112 & 100 & 88 & 88 & 85 & 105 & 88 & 93 & 76 & 110 \\
\hline $\mathrm{Rb}$ & 87 & 79 & 109 & 132 & 42 & 38 & 67 & 44 & 138 & 95 & 86 & 65 & 104 & 65 \\
\hline $\mathrm{Sr}$ & 614 & 541 & 595 & 733 & 646 & 544 & 473 & 540 & 456 & 492 & 537 & 658 & 568 & 475 \\
\hline Y & 15 & 16 & 17 & 16 & 15 & 17 & 23 & 21 & & & 16 & 17 & 17 & 36 \\
\hline $\mathrm{Zr}$ & 188 & 181 & 179 & 181 & 173 & 173 & 181 & 157 & 194 & 216 & 244 & 238 & 244 & 280 \\
\hline $\mathrm{Nb}$ & 11 & 10 & 12 & 13 & 10 & & 12 & 11 & 14 & 13 & 14 & 13 & 14 & 19 \\
\hline $\mathrm{Ba}$ & 549 & 564 & 529 & 664 & 397 & 461 & 496 & 444 & & & 733 & 583 & 728 & 635 \\
\hline La & 28 & 29 & 33 & 41 & 23 & & & 21 & 40 & & 35 & 31 & 37 & 37 \\
\hline $\mathrm{Ce}$ & 56 & 59 & 67 & 78 & 46 & & & 47 & 80 & & 72 & 67 & 73 & 84 \\
\hline $\mathrm{Pr}$ & 7.2 & 6.8 & 8.2 & 9.5 & 5.9 & & & 5.9 & 8.9 & & 8.9 & 8.6 & 9.0 & 10.4 \\
\hline $\mathrm{Nd}$ & 27 & 26 & 30 & 34 & 24 & & & 24 & 33 & & 32 & 31 & 33 & 41 \\
\hline $\mathrm{Sm}$ & 5.1 & 5.1 & 5.8 & 6.1 & 5.0 & & & 5.0 & 6.1 & & 6.0 & 6.3 & 6.1 & 8.4 \\
\hline $\mathrm{Eu}$ & 1.3 & 1.24 & 1.4 & 1.4 & 1.4 & & & 1.6 & 1.4 & & 1.5 & 1.6 & 1.4 & 2.3 \\
\hline $\mathrm{Gd}$ & 4.1 & 4.2 & 4.6 & 4.6 & 4.3 & & & 5.2 & 4.9 & & 4.8 & 5.2 & 4.9 & 7.9 \\
\hline $\mathrm{Tb}$ & & 0.6 & 0.65 & 0.60 & 0.66 & & & 0.72 & 0.64 & & 0.61 & 0.73 & 0.64 & 1.16 \\
\hline Dy & 3.2 & 3.3 & 3.7 & 3.4 & 3.3 & & & 3.6 & 3.5 & & 3.5 & 3.7 & 3.5 & 6.1 \\
\hline Ho & 0.60 & 0.62 & 0.67 & 0.66 & 0.64 & & & 0.66 & 0.62 & & 0.65 & 0.63 & 0.65 & 1.15 \\
\hline $\mathrm{Er}$ & 1.6 & 1.7 & 1.9 & 1.7 & 1.6 & & & 1.8 & 1.8 & & 1.6 & 1.9 & 1.6 & 3.2 \\
\hline $\mathrm{Tm}$ & 0.25 & 0.25 & 0.27 & 0.28 & 0.20 & & & 0.24 & 0.24 & & 0.24 & 0.24 & 0.24 & 0.45 \\
\hline $\mathrm{Yb}$ & 1.4 & 1.5 & 1.6 & 1.6 & 1.3 & & & 1.4 & 1.6 & & 1.5 & 1.5 & 1.5 & 2.7 \\
\hline Lu & 0.20 & 0.22 & 0.25 & 0.24 & 0.20 & & & 0.23 & 0.23 & & 0.22 & 0.25 & 0.22 & 0.43 \\
\hline $\mathrm{Li}$ & 17 & 14 & 23 & 28 & 17 & & 18 & 22 & 31 & 10 & 17 & 12 & 17 & 20 \\
\hline Sc & 15 & 14.2 & 14 & 11 & 18 & & 12 & 16 & 11 & 10 & 8 & 14 & 7 & 16 \\
\hline $\mathrm{Cu}$ & 39 & 42 & 23 & 28 & 52 & & 36 & 45 & 29 & 20 & 38 & 39 & 28 & 39 \\
\hline $\mathrm{Ga}$ & 20 & 21 & 21 & 19 & 20 & & 20 & 21 & 21 & 23 & 24 & 24 & 22 & 23 \\
\hline Mo & 1.4 & 1 & 2.6 & 3.3 & 1.0 & & 1.2 & 1.1 & 2.7 & 2.2 & 1.7 & 1.0 & 1.5 & 1.8 \\
\hline Sn & 1.5 & 2 & 1.5 & 1.5 & 1.4 & & 1.7 & 1.4 & 2.0 & 2.0 & 1.5 & 1.1 & 1.9 & 2.3 \\
\hline Cs & 2.5 & 2.4 & 5.8 & 7.1 & 1.8 & & 2.6 & 1.6 & 7.6 & 2.6 & 3.2 & 1.9 & 3.2 & 2.0 \\
\hline $\mathrm{Ta}$ & 0.7 & 0.7 & 0.9 & 1.1 & 0.5 & & 0.8 & 0.7 & 1.2 & 1.0 & 0.8 & 0.7 & 0.9 & 1.0 \\
\hline $\mathrm{Pb}$ & 9.1 & 9.6 & 10.9 & 13.3 & 6.4 & & 9.0 & 7.7 & 15.5 & 18.2 & 15.0 & 3.7 & 13.2 & 10.6 \\
\hline Th & 10 & 10 & 17 & 20 & $\begin{array}{c}. .4 \\
4\end{array}$ & & 7 & 4 & 23 & 8 & 8 & 7 & 11 & 6 \\
\hline$u$ & 1.9 & 2 & 4.6 & 6.0 & 0.9 & & 2.1 & 1.3 & 6.1 & 1.9 & 1.9 & 1.3 & 2.5 & 1.7 \\
\hline \multicolumn{15}{|c|}{ Isotope initial ratios } \\
\hline${ }^{206} \mathrm{~Pb} /{ }^{204} \mathrm{~Pb}$ & 18.802 & & 18.815 & & 18.721 & & 18.891 & & & 18.680 & & 18.538 & & 18.674 \\
\hline${ }^{207} \mathrm{~Pb} /{ }^{204} \mathrm{~Pb}$ & 15.608 & & 15.612 & & 15.606 & & 15.611 & & & 15.619 & & 15.602 & & 15.605 \\
\hline${ }^{208} \mathrm{~Pb} /{ }^{204} \mathrm{~Pb}$ & 38.734 & & 38.776 & & 38.665 & & 38.702 & & & 38.667 & & 38.698 & & 38.641 \\
\hline${ }^{87} \mathrm{Sr} \mathrm{r}^{\beta 6} \mathrm{Sr}$ & 0.7067 & & 0.7063 & & 0.7064 & & 0.7074 & & & 0.7071 & & 0.7062 & & 0.7058 \\
\hline${ }^{143} \mathrm{Nd} /{ }^{144} \mathrm{Nd}$ & 0.51242 & & 0.51245 & & 0.51243 & & 0.51237 & & & 0.51239 & & 0.51247 & & 0.51249 \\
\hline$\varepsilon \mathrm{Nd}(\mathrm{t})$ & -4.14 & & -3.70 & & -3.97 & & -5.20 & & & -4.61 & & -3.01 & & -2.47 \\
\hline
\end{tabular}

Isotope ratios are calculated from values in Table 4, using the ages given and measured $\mathrm{U}, \mathrm{Th}, \mathrm{Pb}, \mathrm{Sr}, \mathrm{Rb}, \mathrm{Sm}$ and $\mathrm{Nd}$ concentrations. 
Table 4. Isotopic analyses of whole-rock samples from selected ignimbrites and andesite-dacite units from the southern CVZ.

\begin{tabular}{llcccccc} 
Sample & Name/Location & ${ }^{87} \mathrm{Sr} /{ }^{86} \mathrm{Sr}$ & $2 \sigma *$ & ${ }^{143} \mathrm{Nd} /{ }^{144} \mathrm{Nd}$ & $2 \sigma *$ & ${ }^{206} \mathrm{~Pb} /{ }^{204} \mathrm{~Pb}$ & ${ }^{207} \mathrm{~Pb} /{ }^{204} \mathrm{~Pb}$ \\
\hline NEVA-97-5 & Vocán Sierra Nevada & 0.706752 & 10 & 0.512425 & 8 & 18.822 & 15.618 \\
CUY-97-1 & Co. Azufrera de los Cuyanos & 0.706281 & 10 & 0.512448 & 10 & 18.841 & 15.622 \\
LAG-97-1 & Volcán Laguna & 0.706411 & 9 & 0.512434 & 10 & 18.737 & 15.616 \\
CUM-99-1 & Cerros Colorados & 0.707412 & 10 & 0.512370 & 8 & 18.927 & 15.622 \\
PARAD-97-1 & Cerro Piedra Parada & 0.707177 & 9 & 0.512397 & 8 & 18.735 & 15.631 \\
TRIDE-94-1 & Cerro Tridente & 0.706229 & 10 & 0.512478 & 8 & 18.783 & 15.623 \\
GRAN-99-18 & Cerro Puntiagudo de la Isla & 0.705907 & 10 & 0.512504 & 7 & 18.792 & 15.620 \\
& & & & & 38.735 \\
JCO-17-1 & Ignimbrite Laguna Verde & 0.707267 & 10 & 0.512407 & 9 & 18.835 & 15.623 \\
JCO-6-1 & Ignimbrite Wheelwright & 0.706850 & 10 & 0.512419 & 9 & 18.800 & 15.630 \\
JCO-1-1 & Ignimbrite San Andrés & 0.708287 & 10 & 0.512447 & 10 & 18.729 & 38.834 \\
\hline
\end{tabular}

Isotope ratios were measured on unspiked whole-rock samples (see text)

* Uncertainties in measured $\mathrm{Sr}$ and $\mathrm{Nd}$ isotope ratios represent within-run precision and refer to the last digit of given ratios

$\mathrm{Pb}$ isotope ratios were corrected for mass fractionation with $0.11 \%$ per atomic mass unit based on repeated measurements of the NBS981 $\mathrm{Pb}$ standard

$2 \sigma$ uncertainty on $\mathrm{Pb}$ isotope ratios is less than $0.1 \%$.

For initial ratios see Tables 2 and 3 . 